The Canadian Mineralogist

Vol. 41, pp. 1503-1524 (2003)

\title{
TELLURIDE MINERALOGY OF THE GOLDEN MILE DEPOSIT, KALGOORLIE, WESTERN AUSTRALIA
}

\author{
JILL M. SHACKLETON AND PAUL G. SPRY§ \\ Department of Geological and Atmospheric Sciences, 253 Science I, Iowa State University, Ames, Iowa 50011, U.S.A. \\ ROGER BATEMAN ${ }^{\mathbb{I I}}$ \\ Kalgoorlie Consolidated Gold Mines, P.O. Box 27, Kalgoorlie, Western Australia 6433, Australia
}

AbStRact

The Golden Mile, Kalgoorlie, Western Australia, is a mesozonal gold deposit unusual because of its enormous size (>1,457 tonnes of gold) and because tellurides are responsible for approximately $20 \%$ of gold production. Gold mineralization is hosted primarily by Archean-aged dolerites and basalts that have been metamorphosed to the greenschist facies. This mineralization occurs in hundreds of auriferous and telluride-bearing lodes, which have been classified into three structural types on the basis of orientation: main (trending NNW), caunter (trending NW) and cross lodes (trending NE). Three distinct styles of hydrothermal mineralization are present in the deposit. The early Fimiston-style lodes are characterized by main, caunter and cross lodes. The Oroya-style lodes ( $\mathrm{V}$ - and Te-rich) occur in later dilational jogs and veinlets within a shear zone. Both of these are overprinted by the younger Mount-Charlotte-style mineralization (quartz-vein stockwork). Nineteen tellurium-bearing minerals occur in the Golden Mile deposit. Calaverite, petzite, coloradoite, altaite and native gold are most common throughout the deposit, whereas tellurantimony, melonite, hessite, stützite, krennerite and sylvanite are rare in the main and caunter lodes. In addition, hessite and montbrayite are found in trace amounts in the cross and main lodes, respectively. There is no systematic distribution of tellurides within a given lode. Tellurides in Fimiston-style ores formed at $c a .300^{\circ}$ to $170^{\circ} \mathrm{C}$ during cooling of the deposit. Values of $f\left(\mathrm{Te}_{2}\right)$ and $f\left(\mathbf{S}_{2}\right)$ determined at $300^{\circ} \mathrm{C}$ on the basis of the stability of native elements, tellurides and sulfides, are $c a \cdot \log f\left(\mathrm{Te}_{2}\right)$ in the range -11.4 to -6.8 and $\log f\left(S_{2}\right)$ in the range -12.6 to -5.5 . No spatial variations in the composition of native gold, tetrahedrite-group minerals and tellurides occur in the Golden Mile deposit, although there is a weak to moderate decrease in gold fineness with depth. Marked differences in telluride mineralogy in and between individual lodes likely reflect variations in physicochemical conditions during ore formation or mechanisms of precious-metal deposition.

Keywords: Golden Mile, tellurides, gold deposit, paragenetic sequence, mineral zonation, Kalgoorlie, Australia.

\section{SOMMAIRE}

Le gisement aurifère de Golden Mile, dans le district de Kalgoorlie, en Australie occidentale, est un gîte mésozonal inhabituel à cause de sa taille énorme (>1,457 tonnes d'or) et à cause de la présence de tellurures, responsables d'environ $20 \%$ de la production d'or. L'or est surtout dans des dolérites et des basaltes archéens qui ont été métamorphisés au faciès schistes verts. Cette minéralisation a donné lieu à des centaines d'essaims de veines aurifères et tellurifères, qui sont classifiées en trois types structuraux selon leur orientation: essaims principaux (orientation nord - nord-ouest), caunter (orientation nord-ouest) et transversaux (orientation nord-est). Trois styles distincts de minéralisation hydrothermale en résultent. Le stade initial, dit de Fimiston, contient les orientations d'essaims principaux, caunter et transversaux. Les veines de type Oroya (enrichies en V et Te), occupent des décrochements dilationnels et des zones de cisaillement. Ces deux stades de minéralisation sont remaniés lors du stade ultime, dit de type Mont Charlotte (stockwerk de veines de quartz). Dix-neuf minéraux de tellurium ont été repérés dans le gisement de Golden Mile. Calavérite, petzite, coloradoïte, altaïte et or natif sont les plus répandus, tandis que tellurantimoine, mélonite, hessite, stützite, krennerite et sylvanite sont rares dans les essaims principaux et caunter. De plus, hessite et montbrayite se retrouvent en traces dans les essaims transversaux et principaux, respectivement. Il ne semble pas y avoir de distribution systématique des tellurures dans un système de veines. Les tellurures dans le minerai de style Fimiston se seraient formés sur l'intervalle d'environ $300^{\circ}$ à $170^{\circ} \mathrm{C}$ pendant le refroidissement du gisement. Les valeurs de $f\left(\mathrm{Te}_{2}\right)$ et de $f\left(\mathrm{~S}_{2}\right)$ déterminées à $300^{\circ} \mathrm{C}$, en tenant compte de la stabilité des éléments eux-mêmes, des tellurures et des sulfures, se situent environ dans les intervalles de -11.4 à -6.8 et de -12.6 à -5.5 , respectivement. Il n'y a pas de variation spatiale dans la composition de l'or natif, des minéraux

$\S \quad$ E-mail address: pgspry@iastate.edu

II Present address: Mineral Exploration Research Centre, Willet Green Miller Centre, Laurentian University, 933 Ramsey Lake Road, Sudbury, Ontario P3E 6B5, Canada. 
du groupe de la tétraédrite et des tellurures dans le gisement de Golden Mile, quoiqu'il semble y avoir une faible diminution de la pureté de l'or avec la profondeur. Des différences marquées dans la minéralogie des tellurures des essaims de veines et entre ces essaims reflèteraient probablement des variations en conditions physicochimiques au cours de la formation du minerai ou bien en mécanismes de déposition des métaux précieux.

(Traduit par la Rédaction)

Mots-clés: Golden Mile, tellurures, gisement d’or, séquence paragénétique, zonation des minéraux, Kalgoorlie, Australie.

\section{INTRODUCTION}

The Archean Golden Mile deposit, Kalgoorlie, Western Australia, one of the largest mesozonal gold deposits in the world, contains $>1,457$ tonnes Au. Gold in the deposit is mostly found as inclusions of native gold (70$75 \%$ ) in silicates and sulfides, particularly pyrite, but ca. $20 \%$ of it occurs as tellurides (Bateman et al. 2001b). The remainder of the gold (5-10\%) occurs as "invisible gold" [i.e., gold that occurs in solid solution or as colloids < $100 \mathrm{~nm}$ in size (Cook \& Chryssoulis 1990)]. Since 1896, when tellurides were first identified in the Golden Mile (Holroyd 1897), numerous mineralogical studies have been conducted on the ores (e.g., MacIvor 1899, Larcombe 1912, Simpson 1912, Stillwell 1931, Baker 1958, Markham 1960, Travis 1966, Golding 1978). However, only Golding (1978) attempted to evaluate vertical and lateral variations in the distribution of tellurides. Golding reported that the fineness of gold decreases with depth, that montbrayite $\left[(\mathrm{Au}, \mathrm{Sb})_{2}\right.$ $\mathrm{Te}_{3}$ ] is restricted to the edges of the deposit, and that tellurantimony $\left(\mathrm{Sb}_{2} \mathrm{Te}_{3}\right)$ is found only at depth. In addition, she proposed that $\mathrm{Sb}-\mathrm{Ag}-\mathrm{Zn}$-rich tetrahedritegroup minerals occur at depth, whereas As-Fe-rich members exist at shallower levels. The development of the "Super Pit" (a large open-pit operation that, when complete, will span an area $4 \mathrm{~km}$ in length, $1.5 \mathrm{~km}$ in width and $650 \mathrm{~m}$ deep) in 1989 by Kalgoorlie Consolidated Gold Mines afforded access to the different styles of ore throughout the deposit and led to a more systematic study of the spatial distribution of the tellurides.

The aims of the present study of the Golden Mile are to: (i) determine the paragenetic sequence of ore mineralization in the most common style (Fimiston) of goldbearing ore, (ii) refine the geochemical conditions of ore formation based on the stabilities of tellurides, sulfides and native elements, (iii) evaluate the macroscopic distribution of native gold and tellurides, and (iv) investigate potential mechanisms of telluride deposition.

\section{General Geology}

The Golden Mile is located in the Eastern Goldfields of the Norseman-Wiluna Belt in the Yilgarn Craton, Western Australia (Fig. 1). The general geology has been described in detail by, for example, Larcombe
(1912), Golding (1978), Clout (1989), Clout et al. (1990) and Bateman et al. (2001a, b) and is only summarized briefly here.

Gold mineralization is hosted primarily by Archeanaged diabase, gabbro and basalt that have been metamorphosed to the greenschist facies. The Kalgoorlie Goldfield consists of a stratigraphic succession of mafic and ultramafic (komatiitic) rocks (Fig. 2). U-Pb dates on rocks in the Kalgoorlie Goldfield range from $2708 \pm$ $7 \mathrm{Ma}$ for the lowest exposed komatiitic flows of the Hannans Lake Serpentinite to $2681 \pm 5$ Ma for felsic volcanic and volcaniclastic rocks at the top of the succession (Nelson 1997). The high-Mg Devon Consols and Paringa Basalts, the latter of which is strongly contaminated by crustal material (Bateman et al. 2001a), consists of pillowed to massive tholeiitic basalt layered with interflow sedimentary rocks, and overlies the Hannans Lake Serpentinite. Between these two basalt units is the Kapai Slate, which consists of sulfidic mudstone and shale. The entire sequence is overlain by the Black Flag Beds, composed of metamorphosed siltstone, black shale, greywacke, conglomerate, and volcaniclastic and felsic volcanic rocks. Differentiated sills of diabase intruded the volcano-sedimentary sequence. The Williamstown peridotite was emplaced at the boundary between the Kapai Slate and the Paringa Basalt, whereas the Eureka-Federal gabbro intruded the Paringa Basalt unit. The uncontaminated Golden Mile - Aberdare gabbro, which is a thin strongly differentiated sill (Bateman et al. 2001a), occurs at the contact between the Paringa Basalt and Black Flag Bed units. The main hosts to ore are the Golden Mile gabbro and, to a lesser extent, the Paringa basalt (Clout et al. 1990).

Ore at the Golden Mile deposit occurs as auriferous and telluride-bearing lodes, which Finucane \& Jensen (1953) classified into three structural types based on orientation: main (a strike of $315^{\circ}-330^{\circ}$ and a dip of $80-85^{\circ}$ east or west), caunter (a strike of $270-290^{\circ}$ and a dip of $55-70^{\circ}$ south), and cross (a strike of $40-70^{\circ}$ and a steep dip north or south). Individual lodes vary in size from 30 to $1,800 \mathrm{~m}$ long, 0.01 to $10 \mathrm{~m}$ wide, and have a vertical extent of 30 to $1,160 \mathrm{~m}$ (Clout 1989). Orebodies occur along a $7 \mathrm{~km}$ strike length. Gold mineralization in and around the Golden Mile deposit consists of three distinct styles: Fimiston, Oroya and Mount Charlotte. Fimiston-style gold mineralization (named 


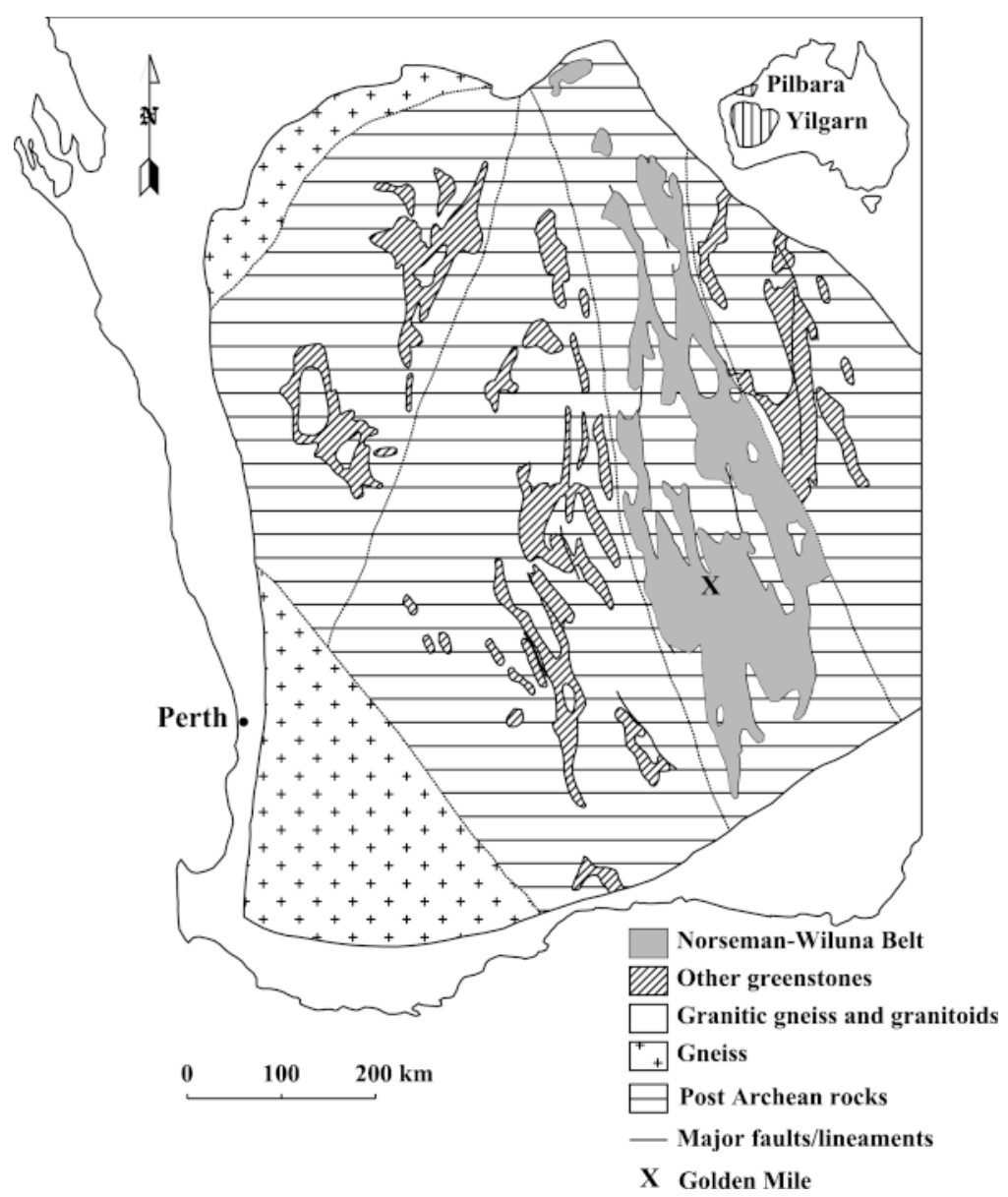

FIG. 1. Geological map of Western Australia showing the location of the Golden Mile deposit within the Archean Norseman-Wiluna greenstone belt.

after the now defunct Fimiston gold mine) accounts for $70 \%$ of gold production within the Golden Mile deposit and consists of auriferous and telluride-bearing shear zones characterized by main, caunter and cross lodes (Clout 1989). Oroya-style ore is located in later dilational jogs and veinlets and is named after the famous gold-rich Oroya Shoot (locally tens of thousands of $\mathrm{g} / \mathrm{t} \mathrm{Au}$ ). This style of ore is characterized by V-bearing minerals and a high proportion of tellurides (Nickel 1977). The Mount Charlotte style of ore postdates Fimiston and Oroya styles of mineralization and is dominated by quartz-stockwork ore (Clout et al. 1990). Because the Mount Charlotte style of mineralization is essentially devoid of tellurides, it will not be a focus of the present study.

Tellurides occur as fine-grained composite aggregates, massive segregations, composite grains with na- tive gold, inclusions in and intergrowths with pyrite and tetrahedrite-group minerals, as well as inclusions in carbonates and various silicates, including quartz and tourmaline. They are best developed at the intersection of lodes or at the intersection between a lode and an unmineralized shear. According to Clout et al. (1990), telluride-rich shoots are more abundant in the upper 200 $\mathrm{m}$ of the deposit, either in the hanging wall of lodes in white mica alteration or in vanadian muscovite alteration along the contact between the Golden Mile Dolerite and the Paringa Basalt.

The Golden Mile is structurally complex, and the relative timing of mineralization is poorly constrained. Bateman et al. (2001b) proposed that four major deformational events affected the Golden Mile area. An initial period of extension was followed by a compressional event $\left(\mathrm{D}_{1}\right)$, consisting of east-over-west thrusting 


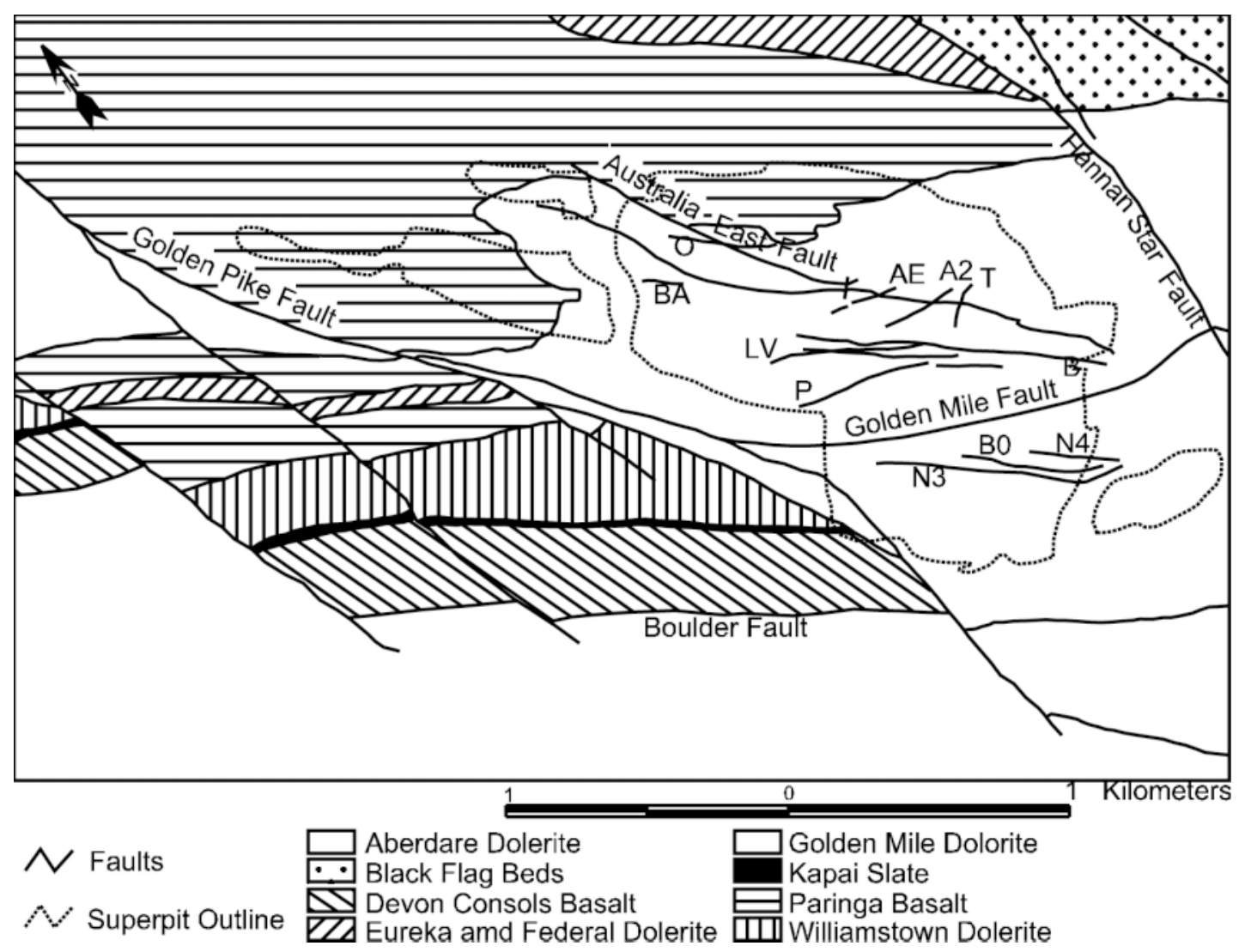

FIG. 2. Geological map of the Golden Mile deposit showing the location of the "Super Pit" and thirteen of the lodes sampled during this study (A2: Associated \#2, AE: Australia East \#3, B: B, BA: Blatchford, BO: Boulder, E: Emerald, F: Furness, LV: Lake View - Main, N3: No. 3 Western, N4: No. 4 Western, O: Oroya, P: Perseverance, T: Tetley).

along the Golden Mile Fault. The second deformational event $\left(\mathrm{D}_{2}\right)$ was east-west compression that formed folds and thrusts. These two gold-mineralization events (Fimiston and Oroya styles) in the Golden Mile deposit were followed by a period of regional left-lateral transpression $\left(\mathrm{D}_{3}\right.$ and $\left.\mathrm{D}_{4}\right)$ comprising right-lateral strike-slip faulting at the scale of the Kalgoorlie Goldfield. $\mathrm{D}_{3}$ was a ductile deformation event, whereas $\mathrm{D}_{4}$ produced brittle structures. Mount-Charlotte-style mineralization is inferred to have formed late during $\mathrm{D}_{3}$ and clearly overprints Fimiston-style mineralization in the "Super Pit." Bateman et al. (2001b) also suggested that greenschist-facies metamorphism occurred prior to and during $\mathrm{D}_{1}$. The findings of Bateman et al. (2001b) have significant implications concerning the origin of the Golden Mile because they also suggested that the lodes were originally emplaced horizontally and later tilted during $\mathrm{D}_{2}$ into their current orientations. This scenario differs dramatically from previous interpretations (e.g., Clout 1989, Clout et al. 1990), in which gold mineralization formed during the waning stages of deformation. Clout et al. (1990) argued that three deformational events affected the Golden Mile area. Although Clout et al. (1990), like Bateman et al. (2001b), believed that $\mathrm{D}_{1}$ consisted of a major thrusting event, they suggested that the ore formed during the latter part of $\mathrm{D}_{2}$ after the development of shear zones, rather than during $D_{1}$. Furthermore, they proposed that $\mathrm{D}_{3}$ produced an anastomosing cleavage followed by hydrothermal alteration that was associated with the formation of Mount-Charlotte-type gold-bearing quartzvein stockworks. Clout et al. concluded that two regional metamorphic events occurred synchronously with $\mathrm{D}_{1}$ (upper-greenschist facies) and $\mathrm{D}_{3}$ (subgreenschist facies). U-Pb and $\mathrm{Ar}-\mathrm{Ar}$ dating techniques (Kent \& McDougall 1995, Yeats \& McNaughton 1997) suggest that syn- $\mathrm{D}_{3}$ (i.e., the age of the Golden Mile mineralization) is approximately $2665 \mathrm{Ma}$, whereas the age of the Mount-Charlotte-style mineralization is approximately $2630 \mathrm{Ma}$ (Bateman et al. 2001a). 


\section{Samples and Analytical TechniQues}

Three hundred and fifty samples were collected from all major structural types of lode and mineralization over a $6 \mathrm{~km}^{2}$ area and to a depth of $1 \mathrm{~km}$. Samples were derived from drill core and taken from the Fimiston-style Furness, Federal, Lake View/Main, No. 2 Western, No. 3 Western, Boulder and B main lodes, the Australia East \#3, Perseverance and Morrison caunter lodes, and the Associated \#2, Tetley and Emerald cross lodes (Fig. 2). Oroya-style samples were collected from the Oroya Shoot and the Oroya, Green Leader and Blatchford lodes. In addition, a few specimens were obtained away from the "Super Pit" at the Mount Charlotte, Abedare, Mount Ferrum, Oratava, Mount Percy and Hannans North deposits for comparative purposes.

Polished thin sections were made from 267 of the samples collected and optically examined using an Olympus BX-60 dual transmitted-reflected light microscope, with special attention being directed toward identifying sulfides, sulfosalts, tellurides and native elements. These minerals were analyzed with an ARLSEMQ electron microprobe at Iowa State University. Operating conditions included a voltage of $20 \mathrm{kV}$, a beam current of $10 \mathrm{nA}$ and a beam diameter of approximately 1 to $2 \mu \mathrm{m}$. We used the following standards: pure metals (for $\mathrm{Au}, \mathrm{Ag}, \mathrm{Te}, \mathrm{Se}$ and $\mathrm{Cu}$ ), natural cinnabar $(\mathrm{HgS})$ for $\mathrm{Hg}$, and the following synthetic minerals: matildite $\left(\mathrm{AgBiS}_{2}\right)$ for $\mathrm{Bi}$, stibnite $\left(\mathrm{Sb}_{2} \mathrm{~S}_{3}\right)$ for $\mathrm{Sb}$, orpiment $\left(\mathrm{As}_{2} \mathrm{~S}_{3}\right)$ for $\mathrm{As}$, galena $(\mathrm{PbS})$ for $\mathrm{Pb}$, sphalerite $[(\mathrm{Zn}, \mathrm{Fe}) \mathrm{S}]$ for $\mathrm{Zn}$, and pyrrhotite $\left(\mathrm{Fe}_{1-x} \mathrm{~S}\right)$ for $\mathrm{Fe}$ and $\mathrm{S}$.

\section{Paragenetic Sequence}

Attempts to determine the paragenetic sequence of hydrothermal mineralization in the Golden Mile deposit are restricted to an investigation of Oroya-style mineralization by Radtke (1963), which was based on a limited number of samples, and to studies by Scantlebury (1983) and Clout (1989) on Fimiston-style mineralization. Clout (1989) identified three different types of alteration in Fimiston-style lodes and documented the paragenesis of each of the main assemblages in these alteration types. The paragenetic sequences for each of these alteration types can be divided into three stages. The first stage is defined by ankerite - white mica quartz - pyrite alteration distal to orebodies. Stage-2 mineralization is dominated by white mica - ankerite siderite - quartz - hematite - pyrite - telluride alteration, which is proximal to the lodes. This was the main stage for the deposition of pyrite and native gold. Stage 3 is characterized by the introduction of tellurides, sulfosalts and sulfides (arsenopyrite, pyrrhotite, sphalerite, chalcopyrite and galena), which are spatially associated with vanadian muscovite - ankerite - quartz siderite - hematite - pyrite alteration. The green colora- tion of the alteration (due to vanadoan white mica) resembles that associated with Oroya-style mineralization. A two-stage paragenetic sequence was identified by Scantlebury (1983), who concluded that two main phases of hydrothermal mineralization exist. His first phase loosely correlates with Clout's (1989) stages 1 and 2, whereas his second phase equates to Clout's stage 3 .

We have complemented the paragenetic studies of Scantlebury (1983) and Clout (1989) with mineralogical observations obtained in the present study and with those of Stillwell (1931), Markham (1960), and Golding (1978) to generate a new paragenetic sequence for the Fimiston-style ores, which more accurately incorporates the paragenesis of tellurides found in Clout's stage 3 (Fig. 3). Early carbonates, quartz, albite and chlorite define the first stage of Fimiston-style mineralization (Clout 1989), whereas pyrite and native gold formed during the latter portion of stage 1. As Clout (1989) reported, this activity was followed by the main stage (i.e., stage 2) of pyrite deposition. Tellurides, tetrahedritegroup minerals and base-metal sulfides constitute the third stage of mineralization, during which native gold and pyrite continued to be deposited. The telluride-forming event can be divided into two and possibly three substages. Stillwell (1931) documented that petzite $\left(\mathrm{Ag}_{3} \mathrm{AuTe}_{2}\right)$ and hessite $\left(\mathrm{Ag}_{2} \mathrm{Te}\right)$ had cross-cut krennerite $\left(\mathrm{AuTe}_{2}\right)$, and also that veins of petzite cross-cut calaverite $\left(\mathrm{AuTe}_{2}\right)$. His findings suggest that an early gold-rich stage, dominated by the assemblage calaverite - native gold, was followed by a later silver-rich stage, consisting of assemblages rich in hessite (hessite - sylvanite - petzite, hessite - sylvanite, hessite - petzite and hessite - native gold). Krennerite, montbrayite, sylvanite $\left[(\mathrm{Au}, \mathrm{Ag})_{2} \mathrm{Te}_{4}\right]$, petzite, coloradoite $(\mathrm{HgTe})$, altaite $(\mathrm{PbTe})$, melonite $\left(\mathrm{NiTe}_{2}\right)$ and tetradymite $\left(\mathrm{Bi}_{2} \mathrm{Te}_{2} \mathrm{~S}\right)$ are commonly found in both the early gold-rich and the later silver-rich assemblages. However, nagyágite $\left[\mathrm{Pb}_{5} \mathrm{Au}\right.$ $(\mathrm{Sb}, \mathrm{Bi}) \mathrm{Te}_{2} \mathrm{~S}_{6}$ ] was reported in contact with calaverite (Markham 1960), but never with the silver-rich tellurides, which suggests that nagyágite formed during the early gold telluride substage. According to Golding (1978), tellurantimony, frohbergite $\left(\mathrm{FeTe}_{2}\right)$ and mattagamite $\left(\mathrm{CoTe}_{2}\right)$ formed late in the telluride paragenesis. However, as none of these tellurides coexists with any precious-metal minerals, their paragenesis remains unclear. One sample documented by Stillwell (1931) shows a vein of stützite that has cross-cut a petzite - hessite assemblage. Thus there may have been a second silver-rich telluride substage dominated by stützite.

In addition to the three main stages of ore mineralization proposed by Clout (1989), we have included a later supergene stage characterized by the presence of covellite and weissite $\left(\mathrm{Cu}_{2-x} \mathrm{Te}\right)$. In this final stage, native gold formed by the decomposition of gold-rich tellurides. 


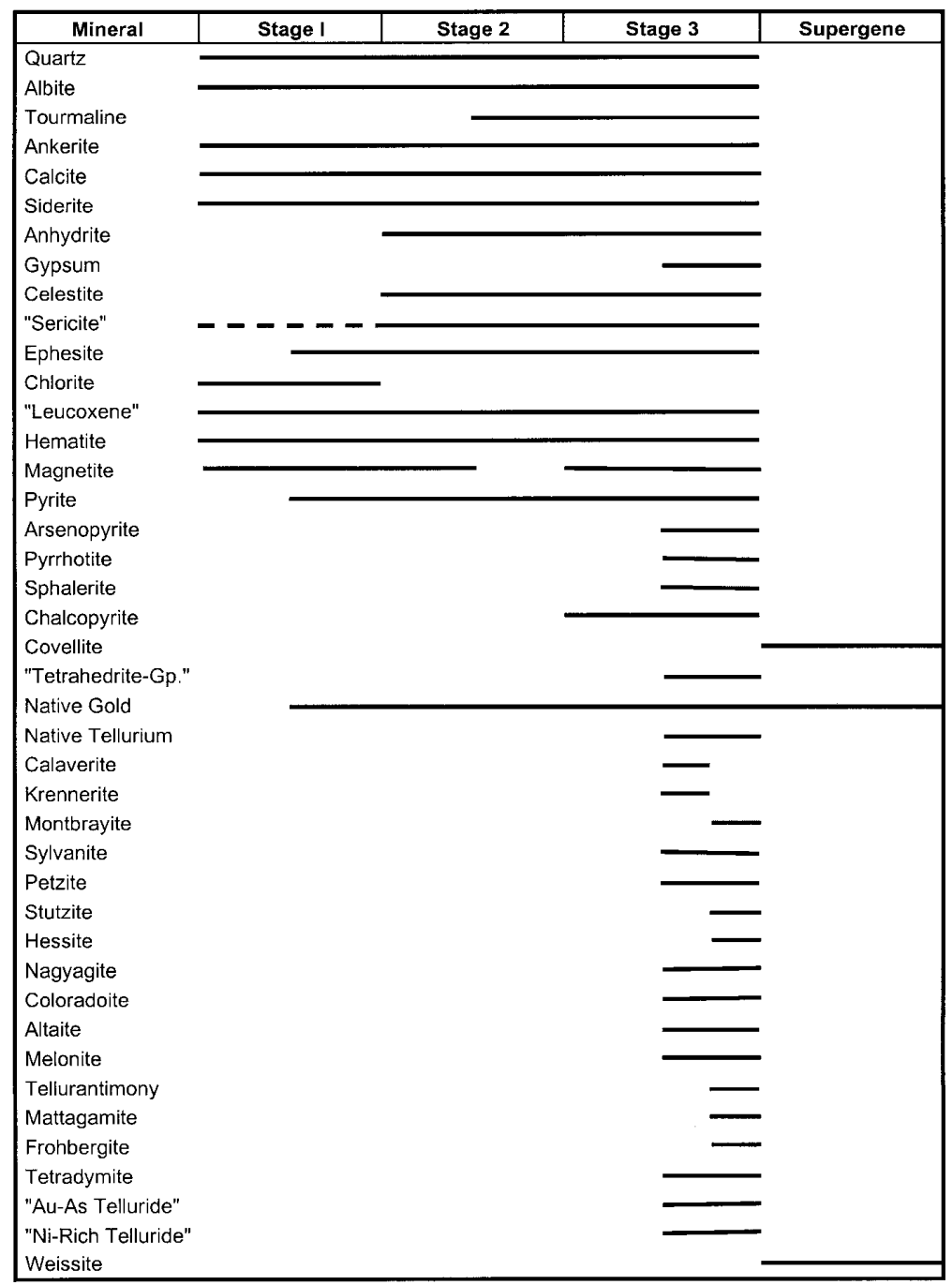

FIG. 3. Paragenetic sequence of Fimiston-style ores at the Golden Mile deposit (modified after Clout 1989).

Major Metallic Minerals Spatially Associated WITH TELLURIDES

\section{Pyrite}

Pyrite is the most common sulfide in the Golden Mile and, along with quartz and carbonates, is the major host for gold, precious metal tellurides and "invisible gold”. Phillips et al. (1988), McQueen et al. (1994) and Hagemann (1999) identified various morphologies of pyrite within the Golden Mile. Although McQueen et al. (1994) recognized three different morphologies of pyrite (cubic, octahedral and pyritohedral), eleven dif- ferent morphologies were subsequently documented by Hagemann (1999). McQueen et al. (1994) identified: (i) aggregates of polygonal to irregular grains of pyrite, (ii) euhedral to subhedral grains of pyrite exhibiting growth zoning, and (iii) smooth subhedral to irregular grains of pyrite that occur near the margin of the other two types of pyrite. They also documented four different textural relationships between pyrite and native gold in the Golden Mile and found that native gold occurs as inclusions in pyrite, along grain boundaries of pyrite, rimming grains of pyrite, and as veinlets in pyrite grains. In the present study, native gold and precious-metal tellurides (calaverite, sylvanite, krennerite and petzite) were 
observed as inclusions in fine-grained disseminated pyritohedral pyrite (Fig. 4A), as infill between grain boundaries of pyrite grains and aggregates (Fig. 4B), as grains along the edges of subhedral pyrite (native gold), and as infill between subhedral pyritohedral pyrite (precious metal tellurides).

Pyrite in the Golden Mile is generally stoichiometric, but some grains contain appreciable quantities of
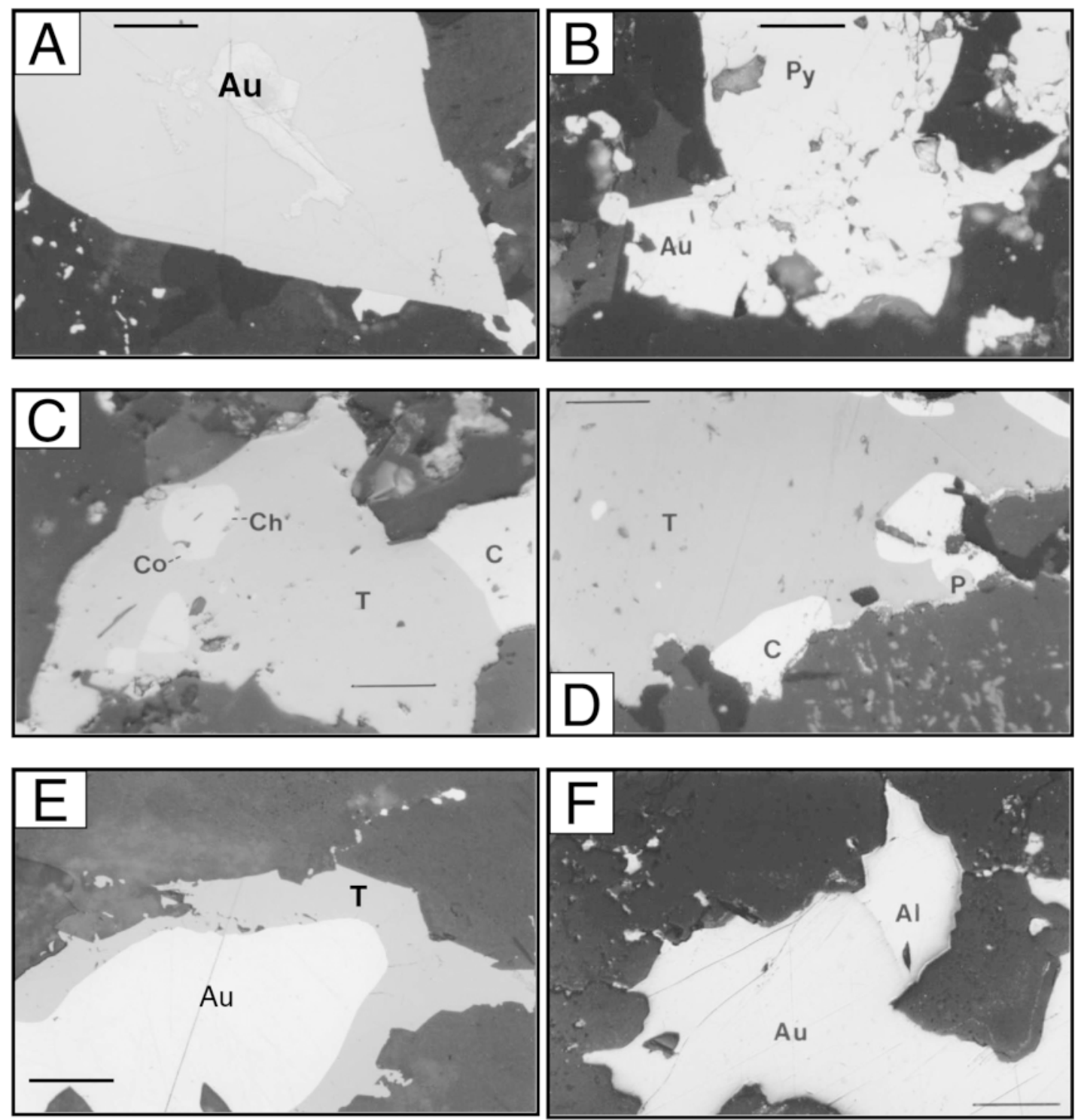

FIG. 4. Reflected light (plane-polarized) photomicrographs of precious-metal minerals (native gold and tellurides) in the Golden Mile deposit. A. Native gold ( $\mathrm{Au}$ ) as an inclusion in and as grains on pyrite (Py) (sample 99KG-297). Scale bar: $0.10 \mathrm{~mm}$. B. Native gold $(\mathrm{Au})$ and pyrite (Py) in carbonate from the Federal eastern main lode (sample 99KG-168). Scale bar: $0.04 \mathrm{~mm}$. C. Tennantite (T) containing inclusions of chalcopyrite $(\mathrm{Ch})$ and coloradoite $(\mathrm{Co})$, coexisting with calaverite $(\mathrm{C})$ in a vein of tourmaline from the Lake View - Main lode (sample 99KG-364A). Scale bar: $0.04 \mathrm{~mm}$. D. Tennantite (T), calaverite (C) and petzite $(\mathrm{P})$ in a vein of tourmaline from the Lake View eastern main lode (sample 99KG-264A). Scale bar: $0.04 \mathrm{~mm}$. E. A grain of native gold $(\mathrm{Au})$ rimmed by tennantite (T) in quartz from Morrison, western caunter lode (sample 99KG-297). Scale bar: 0.10. F. Native $\mathrm{Au}(\mathrm{Au})$ and altaite (Al) in quartz (sample 99KG-202b, No. 2 western lode). Scale bar: $0.10 \mathrm{~mm}$. 
As. McQueen et al. (1994) reported compositional data for eight grains of pyrite from the Golden Mile, four of which contain between 0.19 and 3.22 wt.\% As. Vaughan (1996) and Chryssoulis (1998) undertook analyses of arsenian pyrite from the Golden Mile by secondary ion mass spectrometry (SIMS) with an emphasis on determining whether or not there is a correlation between pyrite morphology and $\mathrm{Au}$ and As contents. Chryssoulis (1998) analyzed three types of pyrite: coarse, porous and microcrystalline for $\mathrm{Au}$ and As. Gold concentrations of coarse, porous, and microcrystalline pyrite varies from 0.14 to $1.70 \mathrm{ppm}$ (average: $0.56 \mathrm{ppm}$ ), 0.16 to $87 \mathrm{ppm}$ (average: $21 \mathrm{ppm}$ ) and 0.18 to $28 \mathrm{ppm}$ (average: 5.0 $\mathrm{ppm}$ ), respectively. However, it should be noted that two grains of pyrite contain $>10 \mathrm{wt} \%$ As (Fig. 5). Using the SIMS data of Vaughan (1996) and Chryssoulis (1998) and the data generated by laser-ablation inductively coupled plasma - mass spectrometry of Bateman (1998), Bateman et al. (2001b) estimated that "invisible gold" constitutes 5-10\% of the total volume of gold in the deposit.

On the basis of our electron-microprobe results (Table 1), the As content of 50 pyrite grains from 33 different samples ranges from 0 to $8.97 \mathrm{wt} . \%$, with the finer subhedral to anhedral grains of pyrite $(0.1 \mathrm{~mm})$ containing the highest As contents. Such a relationship is consistent with the findings of Chryssoulis (1998).

Petrographic studies by us reveal that porous pyrite contains the highest proportion of visible tellurides and native gold. These observations are compatible with those of Phillips et al. (1988) and McQueen et al. (1994), who concluded that porous pyrite contains higher quantities of visible gold than the other textural varieties of pyrite.

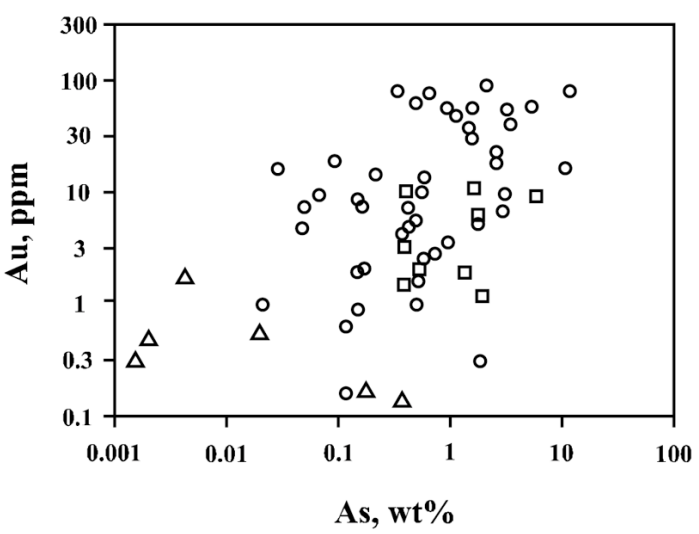

FIG. 5. A plot of As (weight \%) versus $\mathrm{Au}(\mathrm{ppm})$ in pyrite of different morphologies from the leach pyrite residue (Chryssoulis 1998). Data from SIMS analyses. Symbols: $\bigcirc$ porous, $\triangle$ coarse, $\square$ microcrystalline. Reprinted with permission.

\section{Tetrahedrite-group minerals}

After pyrite, tetrahedrite-group minerals constitute the next most common host for tellurides. Both tetrahedrite and tennantite were found in samples containing coloradoite (Fig. 4C), hessite, calaverite (Figs. 4C, D), petzite (Fig. 4D), tellurantimony, melonite, altaite and native gold (Fig. 4E). Although tetrahedrite was identified in a sample containing montbrayite, only tennantite was found in samples containing sylvanite and krennerite. Golding (1978) reported that calaverite is spatially associated with tennantite, whereas native gold, altaite, petzite, tellurantimony and hessite occur in contact with tetrahedrite.

Hopkins (1965) proposed that a correlation exists between gold grade (up to $15 \mathrm{ppm}$ ) and the As content of tetrahedrite-group minerals in the Perseverance lode. Determining the distribution of tennantite $\left[(\mathrm{Cu}, \mathrm{Fe})_{12}\right.$ $\mathrm{As}_{4} \mathrm{~S}_{13}$ ] could thus be useful for exploration purposes, and there may be a compositional relationship between tetrahedrite-group minerals and gold-bearing tellurides. To evaluate whether or not there is a spatial variation in chemical composition, sixty-eight samples were ana-

\begin{tabular}{|c|c|c|c|c|c|c|c|}
\hline 1 & 2 & 3 & 4 & 5 & 6 & 7 & 8 \\
\hline 46.72 & 50.91 & 52.02 & 52.86 & 25.34 & 28.14 & 27.94 & 28.17 \\
\hline 45.76 & 46.48 & 45.70 & 46.12 & 5.18 & 7.13 & 4.39 & 4.57 \\
\hline 0.08 & 0.08 & 0.00 & 0.01 & 34.20 & 41.93 & 41.37 & 39.67 \\
\hline 0.00 & 0.00 & 0.00 & 0.00 & 1.75 & 0.86 & 3.81 & 3.26 \\
\hline 8.97 & 2.90 & 1.02 & 0.00 & 0.21 & 19.55 & 17.05 & 14.15 \\
\hline 0.13 & 0.81 & 0.00 & 0.02 & 0.00 & 0.28 & 0.67 & 0.00 \\
\hline 0.02 & 0.02 & 0.02 & 0.03 & 3.96 & 0.12 & 0.17 & 0.16 \\
\hline 0.00 & 0.01 & 0.00 & 0.01 & 27.98 & 0.52 & 5.21 & 9.25 \\
\hline 0.00 & 0.00 & 0.00 & 0.00 & 0.00 & 0.00 & 0.00 & 0.00 \\
\hline 0.00 & 0.10 & 0.14 & 0.29 & 0.00 & 0.00 & 0.00 & 0.00 \\
\hline 0.06 & 0.00 & 0.34 & 0.37 & 0.00 & 0.00 & 0.00 & 0.00 \\
\hline 0.03 & 0.03 & 0.30 & 0.14 & 0.00 & 0.00 & 0.00 & 0.00 \\
\hline 0.19 & 0.18 & 0.16 & 0.09 & 0.05 & 0.05 & 0.11 & 0.18 \\
\hline 101.96 & 101.52 & 99.70 & 99.95 & 98.66 & 98.58 & 100.73 & 99.41 \\
\hline 1.821 & 1.927 & 1.980 & 1.995 & 13.000 & 13.000 & 13.000 & 13.000 \\
\hline 1.023 & 1.010 & 0.998 & 0.999 & I.525 & 1.892 & 1.172 & 1.210 \\
\hline 0.002 & 0.002 & 0.000 & 0.000 & 8.852 & 9.771 & 9.712 & 9.238 \\
\hline 0.000 & 0.000 & 0.000 & 0.000 & 0.440 & 0.195 & 0.870 & 0.737 \\
\hline 0.149 & 0.047 & 0.017 & 0.000 & 0.047 & 3.865 & 3.395 & 2.795 \\
\hline 0.000 & 0.012 & 0.000 & 0.000 & 0.000 & 0.053 & 0.127 & 0.000 \\
\hline 0.000 & 0.000 & 0.000 & 0.000 & 0.604 & 0.016 & 0.024 & 0.023 \\
\hline 0.000 & 0.000 & 0.000 & 0.000 & 3.778 & 0.064 & 0.638 & 1.124 \\
\hline 0.000 & 0.000 & 0.000 & 0.000 & 0.000 & 0.000 & 0.000 & 0.000 \\
\hline 0.000 & 0.001 & 0.000 & 0.000 & 0.000 & 0.000 & 0.000 & 0.000 \\
\hline 0.000 & 0.000 & 0.002 & 0.002 & 0.000 & 0.000 & 0.000 & 0.000 \\
\hline 0.001 & 0.000 & 0.002 & 0.001 & 0.000 & 0.000 & 0.000 & 0.000 \\
\hline 0.001 & 0.001 & 0.001 & 0.000 & 0.004 & 0.003 & 0.008 & 0.013 \\
\hline
\end{tabular}

1. Pyrite, 99KG-254, No. 3, western main lode; 2. Pyrite, 99KG-297, Morrison, western caunter lode; 3. Pyrite, 99KG-44B, B, eastern main lode; 4. Pyrite, 99KG-251, Federal, eastern main lode; 5. Tetrahedrite, 99KG-269, Emerald, eastern cross lode; 6. Tennantite, 99KG-14, Blatchford, Oroya; 7. Tennantite, 99KG-93A, No 4, western main lode; 8 . Tennantite, 99KG-260, No. 3, western main lode. Electronmicroprobe data, recalculated on the basis of three atoms per formula unit (pyrite) or thirteen atoms of sulfur (tetrahedrite-group minerals). 
lyzed to complement twenty-four compositions obtained by Golding (1978). All the data we obtained are listed in Shackleton (2002), and representative compositions are given in Table 1 . The $\mathrm{As} /(\mathrm{Sb}+\mathrm{As})$ value of tetrahedrite-group minerals in the Golden Mile deposit ranges from 0 to 1 . They also display a highly variable $\mathrm{Zn}: \mathrm{Fe}$ ratio (Fig. 6, Table 1). Not only is there a marked variation in composition of the tetrahedrite-group minerals laterally and vertically within the deposit, but wide compositional variations also are present in individual types of lode and within individual samples. A notable feature of the composition of tetrahedrite-group minerals is that they generally contain $<1.0 \mathrm{wt} . \% \mathrm{Ag}$, which is in keeping with the low overall $\mathrm{Ag}$ :Au ratio of the ore. Sample 99KG-269 from the Emerald lode proved to be an exception, as it contains up to 3.96 wt.\% Ag. None of the tetrahedrite-group minerals contain detectable $\mathrm{Te}$ (Table 1), and we conclude that there is no compositional relationship between tetrahedrite-group minerals and tellurides.

\section{Native gold}

Gold in the Golden Mile deposit occurs mostly as inclusions of native gold in carbonates, silicates (quartz and tourmaline) and as intergrowths with and as inclusions in sulfides [pyrite (Fig. 4A) and chalcopyrite], tetrahedrite-group minerals (Fig. 4E) and precious-metal tellurides (Golding 1978) (Fig. 4F). Values of fineness $[1000 \mathrm{Au} /(\mathrm{Au}+\mathrm{Ag})]$ obtained herein from thirty-two samples $(n=55)$ range from 901 to 972 , which is simi-

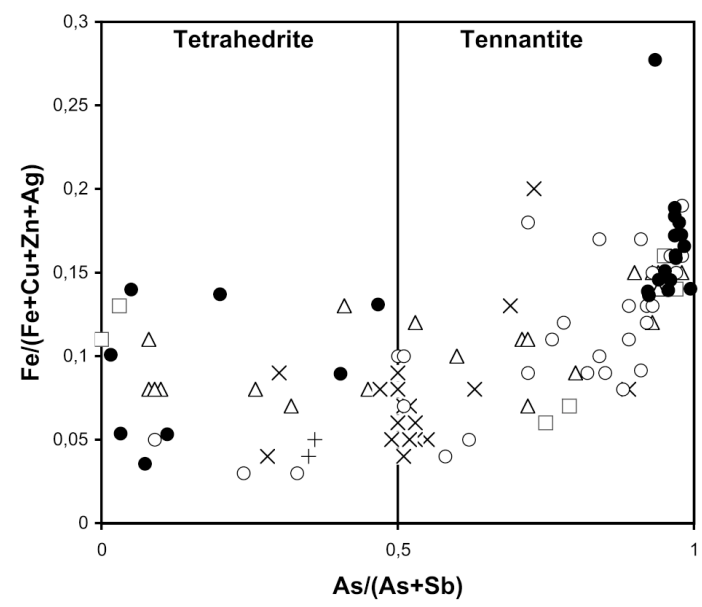

FIG. 6. Chemical variation of tetrahedrite-group minerals from Fimiston-style ores as a function of $\mathrm{Fe} /(\mathrm{Zn}+\mathrm{Cu}+\mathrm{Fe}$ + Ag) versus As/(As + Sb). Symbols: $\triangle$ Eastern Main, $X$ Eastern Caunter, $\square$ Eastern Cross, $\bigcirc$ Western Main, + Western Caunter, and Golding (1978). lar to the range of 949 to 956 reported by Golding (1978). However, she also documented eight compositions with $>5$ wt.\% Ag. McQueen et al. (1994) revealed a fineness range of 898 to $957(n=18)$. Data derived from these three studies serve to illustrate the uniformity in gold compositions and the gold-rich nature of the gold-silver alloys in the Golden Mile deposit.

\section{The Telluride Minerals}

Nineteen tellurium-bearing minerals were previously identified in the Golden Mile deposit (Fig. 3) (e.g., Stillwell 1931, Markham 1960, Travis 1966, Golding 1978). Some of these minerals are rare. In the present study, the following tellurides were identified: coloradoite, calaverite, petzite, krennerite, sylvanite, hessite, altaite, melonite, montbrayite, and tellurantimony. In Table 2, we summarize the relative abundance and distribution of native gold and some tellurium-bearing minerals in Fimiston-style mineralization. Calaverite and petzite are the most prevalent precious-metal tellurides, whereas coloradoite is the most common telluride. Representative compositions of tellurides are given in Table 3. All compositions of tellurides and other minerals obtained as part of this study are listed in Shackleton (2002).

\section{Calaverite}

Calaverite occurs in each of the three major types of lode at depths from 101 to $667 \mathrm{~m}$ below the present-day surface. Grains of calaverite (up to $0.3 \mathrm{~mm}$ in length) coexist with native gold as well as montbrayite, sylvanite, petzite (Fig. 4D), coloradoite, altaite (Fig. 7A) and tellurantimony. Calaverite also occurs as inclusions in pyrite and in assemblages with tennantite (Figs. 4C, D). Calaverite was reported previously in contact with

\begin{tabular}{|c|c|c|c|c|}
\hline Mineral & & Main Lodes & Caunter Lodes & Cross Lodes \\
\hline Native gold & $\mathrm{Au}$ & $\mathrm{XXX}$ & $\mathrm{XX}$ & $\mathrm{x}$ \\
\hline Calaverite & $\mathrm{AuTe}_{2}$ & $\mathrm{XXX}$ & $\mathrm{XX}$ & $\mathrm{x}$ \\
\hline Montbrayite & $(\mathrm{Au}, \mathrm{Sb})_{2} \mathrm{Te}_{3}$ & $\mathrm{~T}$ & $\mathrm{O}$ & $\mathrm{O}$ \\
\hline Krennerite & $\mathrm{AuTe}_{2}$ & $\mathrm{~T}$ & $\mathrm{X}$ & $\mathrm{O}$ \\
\hline Sylvanite & $(\mathrm{Ag}, \mathrm{Au})_{2} \mathrm{Te}_{4}$ & $\mathrm{~T}$ & $\mathrm{X}$ & O \\
\hline Petzite & $\mathrm{Ag}_{3} \mathrm{AuTe}_{2}$ & $\mathrm{XXX}$ & $\mathrm{XXXX}$ & $\mathrm{XXX}$ \\
\hline Stützite & $\mathrm{Ag}_{5 . x} \mathrm{Te}_{3}$ & $\mathrm{~T}$ & $\mathrm{~T}$ & $\mathrm{O}$ \\
\hline Iicssite & $\mathrm{Ag}_{2} \mathrm{Te}$ & $\mathrm{X}$ & $\mathrm{X}$ & $\mathrm{T}$ \\
\hline Coloradoite & $\mathrm{HgTe}$ & $\mathrm{xxx}$ & $\mathrm{XX}$ & $\mathrm{X}$ \\
\hline Altaite & $\mathrm{PbTe}$ & $\mathrm{XX}$ & $\mathrm{XXXX}$ & $\mathrm{XX}$ \\
\hline Tellurantimony & $\mathrm{Sb}_{2} \mathrm{Te}_{3}$ & $\mathrm{~T}$ & $\mathrm{X}$ & $\mathrm{O}$ \\
\hline Melonite & $\mathrm{NiTe}_{2}$ & $\mathrm{X}$ & $\mathrm{T}$ & $\mathrm{O}$ \\
\hline Native tellurium & $\mathrm{Te}$ & 0 & $\mathrm{O}$ & $\mathrm{T}$ \\
\hline
\end{tabular}

$\mathrm{XXXX}$ : abundant, $\mathrm{XXX}$ : relatively common, $\mathrm{XX}$ : common, $\mathrm{X}$ : rare, $\mathrm{T}$ : trace, $\mathrm{O}$ : absent. * Modified after Stokes (1989). 
montbrayite (Travis 1966, Golding 1978), krennerite (Travis 1966), sylvanite (Stillwell 1931), melonite (Stillwell 1931), tellurantimony (Stokes 1989), tetradymite (Markham 1960), mattagamite (Golding 1978), frohbergite (Golding 1978), and native Te (Golding 1978). Calaverite analyzed in the present study contains 0.28 to $2.69 \mathrm{wt} . \% \mathrm{Ag}$, up to $0.58 \mathrm{wt}$. $\% \mathrm{Sb}$, and up to $0.18 \mathrm{wt} \% \mathrm{Cu}$ (Shackleton 2002). These compositions are mostly consistent with those reported by Golding (1978), although one grain of calaverite analyzed by Golding was found to contain $2.2 \mathrm{wt} . \% \mathrm{Sb}$.

\section{Montbrayite}

Montbrayite is a rare gold telluride that appears to require the presence of impurities $(\mathrm{Sb}, \mathrm{Bi}, \mathrm{Ag}$ and $\mathrm{Pb}$ ) to stabilize its structure (Shackleton \& Spry 2003). In the present study, grains of montbrayite up to $0.10 \mathrm{~mm}$ in size were found in contact with native gold, petzite and altaite (Figs. 7B, C) in quartz from a sample from the No. 2 Western lode. It was also found in contact with pyrite in the Oroya shoot. Other studies of montbrayite from the Golden Mile show that it coexists with calaverite (Travis 1966, Stokes 1989), sylvanite (Travis 1966) and melonite (Travis 1966). The montbrayite analyzed here contains up to $7.46 \mathrm{wt} . \% \mathrm{Sb}$.

TABLE 3. REPRESENTATIVE COMPOSITIONS OF TELLURIDES. GOLDEN MILE DEPOSIT

\begin{tabular}{|c|c|c|c|c|c|c|c|c|c|}
\hline & 1 & 2 & 3 & 4 & 5 & 6 & 7 & 8 & 9 \\
\hline $\mathrm{Fe}$ wt. $\%$ & 0.00 & 0.00 & 0.00 & 0.00 & 0.00 & 0.06 & 0.00 & 0.00 & 0.06 \\
\hline $\mathrm{Cu}$ & 0.00 & 0.00 & 0.00 & 0.00 & 0.00 & 0.09 & 0.03 & 0.00 & 0.06 \\
\hline $\mathrm{Zn}$ & 0.00 & 0.00 & 0.00 & 0.00 & 0.04 & 0.03 & 0.00 & 0.00 & 0.00 \\
\hline $\mathrm{Ag}$ & 0.28 & 5.19 & 12.93 & 40.30 & 40.31 & 61.49 & 0.18 & 0.00 & 0.06 \\
\hline $\mathrm{Sb}$ & 0.01 & 0.00 & 0.00 & 0.00 & 0.00 & 0.00 & 0.00 & 0.00 & 37.38 \\
\hline As & 0.00 & 0.00 & 0.00 & 0.00 & 0.00 & 0.00 & 0.00 & 0.00 & 1.12 \\
\hline $\mathrm{Te}$ & 57.35 & 59.63 & 64.11 & 32.49 & 33.64 & 34.45 & 38.85 & 1.00 & 60.79 \\
\hline $\mathrm{Au}$ & 43.11 & 33.64 & 23.00 & 26.19 & 25.25 & 0.00 & 0.00 & 0.00 & 0.06 \\
\hline $\mathrm{Pb}$ & 0.00 & 0.00 & 0.00 & 0.00 & 0.00 & 0.00 & 0.00 & 60.36 & 0.49 \\
\hline $\mathrm{Hg}$ & 0.00 & 0.00 & 0.00 & 0.00 & 0.00 & 0.00 & 60.78 & 0.45 & 0.00 \\
\hline $\mathrm{Bi}$ & 0.00 & 0.00 & 0.00 & 0.00 & 0.00 & 0.15 & 0.00 & 0.42 & 0.07 \\
\hline Total & 100.75 & 98.46 & 100.05 & 98.72 & 99.23 & 99.27 & 99.57 & 101.601 & 100.09 \\
\hline $\mathrm{Fe} a p f u$ & 0.000 & 0.000 & 0.000 & 0.000 & 0.000 & 0.003 & 0.000 & 0.000 & 0.007 \\
\hline $\mathrm{Cu}$ & 0.000 & 0.000 & 0.000 & 0.000 & 0.000 & 0.005 & 0.001 & 0.000 & 0.006 \\
\hline $\mathrm{Zn}$ & 0.000 & 0.000 & 0.000 & 0.000 & 0.004 & 0.002 & 0.000 & 0.000 & 0.000 \\
\hline$\Lambda \mathrm{g}$ & 0.010 & 0.206 & 0.954 & 2.915 & 2.834 & 1.942 & 0.005 & 0.000 & 0.004 \\
\hline $\mathrm{Sb}$ & 0.000 & 0.000 & 0.000 & 0.000 & 0.000 & 0.000 & 0.000 & 0.000 & 1.933 \\
\hline As & 0.000 & 0.000 & 0.000 & 0.000 & 0.000 & 0.000 & 0.000 & 0.000 & 0.094 \\
\hline $\mathrm{Te}$ & 2.000 & 2.000 & 4.000 & 2.000 & 2.000 & 1.000 & 1.000 & 1.000 & 3.000 \\
\hline $\mathrm{Au}$ & 0.970 & 0.742 & 0.930 & 1.044 & 0.972 & 0.000 & 0.000 & 0.000 & 0.002 \\
\hline $\mathrm{Pb}$ & 0.000 & 0.000 & 0.000 & 0.000 & 0.000 & 0.000 & 0.000 & 1.001 & 0.015 \\
\hline $\mathrm{Hg}$ & 0.000 & 0.000 & 0.000 & 0.000 & 0.000 & 0.000 & 0.995 & 0.007 & 0.000 \\
\hline $\mathrm{Bi}$ & 0.000 & 0.000 & 0.000 & 0.000 & 0.000 & 0.002 & 0.000 & 0.005 & 0.002 \\
\hline
\end{tabular}

1. Calaverite, 99KG-281, Associated $\$ 2$, eastern cross lode. 2. Krennerite, 99KG-264B, Lake View, eastern main lode. 3. Sylvanite, 99KG-202A, No. 2, western main lode. 4. Petzite, 99KG-203, No. 2, western main lode. 5. Petzite, $99 \mathrm{KG}-44 \mathrm{C}, \mathrm{B}$, eastern main lode. 6 . Hessite, $99 \mathrm{KG}-5$, Oratava, regional sample. 7. Coloradoite, 99KG-330, Furness lode. 8. Altaite, 99KG-141, Oroya Shoot. 9. Tellurantimony, 99KG-44A, B, eastern main lode. The results of electron-microprobe analyses are recast in terms of atoms per formula unit (apfu) on the basis of the number of tellurium atoms indicated.
As a result of a detailed discussion, Shackleton \& Spry (2003) argued that the formula of $(\mathrm{Au}, \mathrm{Sb})_{2} \mathrm{Te}_{3}$ for montbrayite may be inappropriate, and that it is more likely to be $(\mathrm{Au}, \mathrm{Ag}, \mathrm{Sb}, \mathrm{Bi})_{2}(\mathrm{Te}, \mathrm{Sb}, \mathrm{Bi})_{3}$.

\section{Krennerite}

In the present study, krennerite $(0.3 \mathrm{~mm}$ across $)$ was found in only one sample from the Lake View Eastern Main lode, where it coexists with quartz in coloradoite (Fig. 7D). However, krennerite was identified previously in the Golden Mile in contact with native gold and calaverite (Travis 1966), sylvanite (Travis 1966), petzite (Stillwell 1931, Travis 1966), stützite (Golding 1978), hessite (Stillwell 1931, Travis 1966), altaite (Stillwell 1931), nagyágite (Markham 1960), melonite (Stillwell 1931) and weissite (Stillwell 1931). Compositions reported by Shackleton (2002) show that the Ag content of krennerite ranges from 3.68 to $5.19 \mathrm{wt} . \%$, which is similar to the range reported by Golding (1978).

\section{Sylvanite}

Two samples of sylvanite were found in the present study. One sample was collected from the No. 2 Western lode, whereas the second sample came from the Lake View - Main lode. In both samples, sylvanite occurs in contact with calaverite and altaite. Sylvanite also coexists with calaverite (Stillwell 1931, Markham 1960), montbrayite (Travis 1966), krennerite (Travis 1966), petzite (Stillwell 1931, Travis 1966, Markham 1960), stützite (Golding 1978, Markham 1960), hessite (Stillwell 1931, Baker 1958, Markham 1960), coloradoite (Markham 1960), altaite (Stillwell 1931, Baker 1958, Markham 1960), melonite (Baker 1958), weissite and native tellurium (Golding 1978, Markham 1960).

The composition of sylvanite (11.74 to $12.93 \mathrm{wt} . \%$ $\mathrm{Ag}$ ) obtained herein is similar to that reported by Golding (1978) (Table 3). Golding found sylvanite in an assemblage of krennerite - sylvanite - petzite coloradoite with a wide range of silver contents ( 6.10 to $13.10 \mathrm{wt} . \% \mathrm{Ag})$. Silver-rich sylvanite is to be expected where it forms in equilibrium with petzite, whereas Agpoor sylvanite will likely occur in contact with krennerite (Fig. 8).

\section{Petzite}

Like calaverite, petzite has a wide spatial distribution and occurs in all major types of lode. It was found at depths ranging from 101 to $678 \mathrm{~m}$ below the surface. Petzite grains, up to $0.1 \mathrm{~mm}$ in length, coexist with calaverite (Fig. 4D), montbrayite (Fig. 7B), hessite, coloradoite, altaite, tellurantimony, native gold (Fig. 7C) and tennantite (Fig. 4D). Petzite also occurs in contact with krennerite (Travis 1966, Golding 1978), sylvanite (Stillwell 1931, Markham 1960, Travis 1966), melonite 

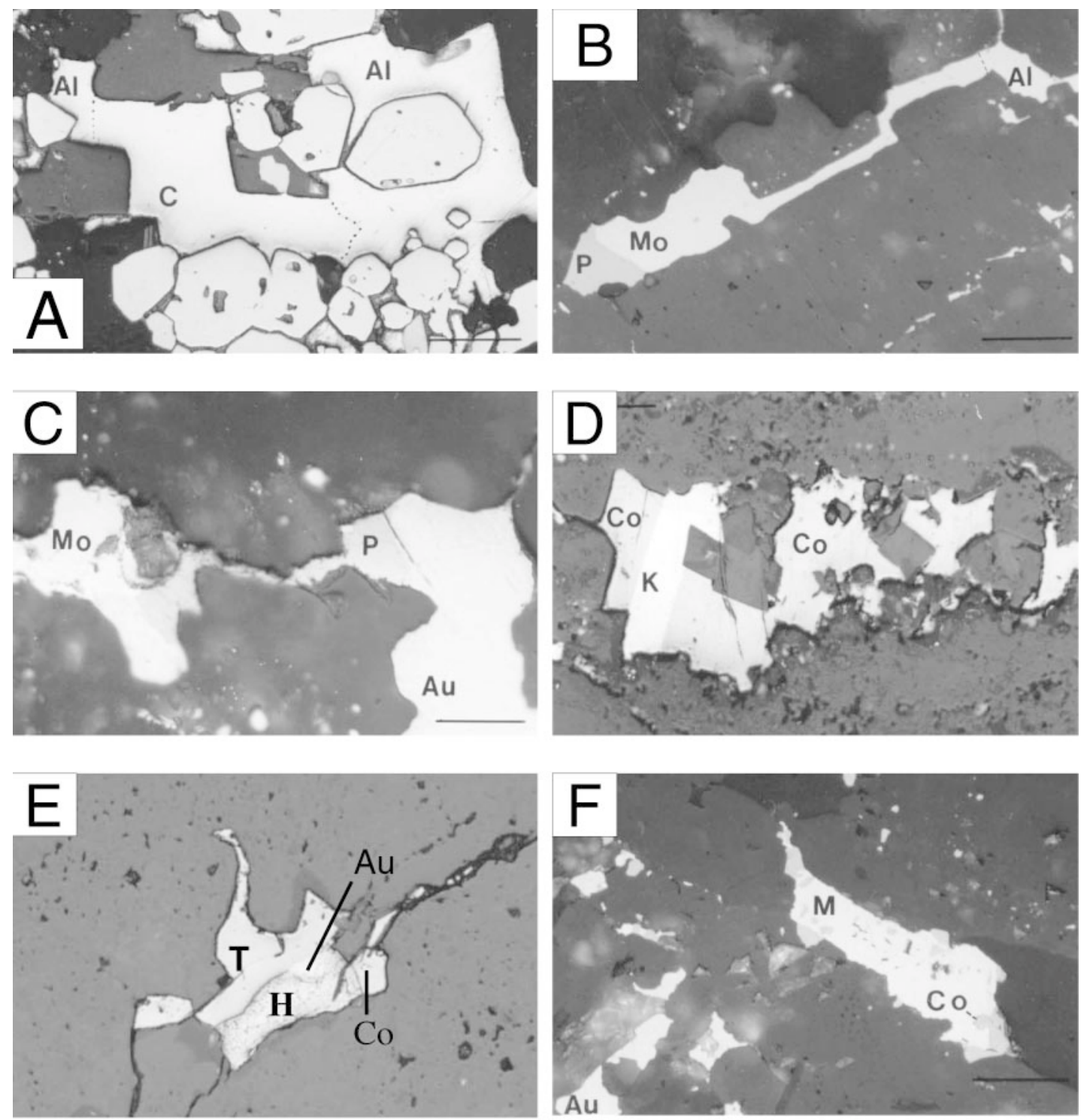

FIG. 7. Reflected light (plane-polarized) photomicrographs of precious-metal minerals (native gold and tellurides) in the Golden Mile deposit. A. Altaite (Al) and calaverite (C) intergrown with grains of pyrite in quartz (sample 99KG-202, No. 2 western lode). Scale bar: $0.10 \mathrm{~mm}$. B. Montbrayite (Mo) coexisting with petzite $(\mathrm{P})$ and altaite (Al) in quartz (sample 99KG-202B, No. 2 western lode). Scale bar: $0.04 \mathrm{~mm}$. C. Montbrayite (Mo), petzite (P) and native gold (Au) in quartz (sample 99KG-202, No. 2 western lode). Scale bar: $0.04 \mathrm{~mm}$. D. Coloradoite (Co) coexisting with krennerite (K) in quartz (sample 99KG-264A, Lake View eastern main lode). Scale bar: $0.20 \mathrm{~mm}$. E. Tennantite (T) coexisting with native gold (Au), coloradoite (Co) and hessite $(\mathrm{H})$ in carbonate (sample 99KG-301, Boulder western main lode). Scale bar: $0.10 \mathrm{~mm}$. F. Melonite (M) intergrown with coloradoite $(\mathrm{Co})$ near grains of native gold $\mathrm{Au}$ ) in carbonate (sample 99KG-168, Federal eastern main lode). Scale bar: $0.04 \mathrm{~mm}$. 
(Markham 1960, Travis 1966), nagyágite (Markham 1960) and tetradymite (Markham 1960).

Most compositions of petzite from the Golden Mile deposit are close to being stoichiometric, although some grains show slight enrichments in Ag (Shackleton 2002). The silver contents of petzite range from 40.03 to $43.76 \mathrm{wt} . \%$ (Table 3 ). This compositional variation is attributed to steep gradients in thermal and electric fields that occur around the electron-impact spot, resulting in the diffusion of gold during the electron-microprobe analysis (Rucklidge \& Stumpfl 1968).

\section{Coloradoite}

Coloradoite is the most common non-precious telluride found in the Golden Mile deposit. It occurs in all major types of lode as grains up to $0.6 \mathrm{~mm}$ in size in assemblages with native gold (Fig. 7E), calaverite, krennerite (Fig. 7D), sylvanite, petzite, altaite and melonite (Fig. 7F), and as inclusions within tetrahedritegroup minerals and pyrite. Coloradoite also occurs as individual grains in quartz and carbonate and with other tellurides, including hessite (Baker 1958, Markham 1960), nagyágite (Markham 1960), tellurantimony (Travis 1966), tetradymite (Markham 1960) and weissite (Baker 1958).
Cuprian coloradoite (11.50 and 12.14 wt. $\% \mathrm{Cu}$ ) was identified by Radtke (1963) in the Oroya Shoot associated with coloradoite, calaverite, petzite, sylvanite and native gold. It has not been reported at the Golden Mile, or elsewhere, since its initial discovery by Radtke.

\section{Altaite}

Altaite is a fairly common accessory mineral in the Golden Mile. In this study, altaite grains up to $0.4 \mathrm{~mm}$ in length were observed in seven samples from various main lodes, in three samples from Oroya-type mineralization, and in one sample from the Oratava lode (north of the Golden Mile). It occurs in contact with native gold (Fig. 4F), calaverite (Fig. 7A), montbrayite (Fig. 7B), petzite, hessite, tellurantimony and coloradoite. Previous investigators also reported altaite touching krennerite (Golding 1978, Stokes 1989), sylvanite (Stillwell 1953), melonite (Markham 1960) and native tellurium (Travis 1966).

\section{Miscellaneous tellurides}

Hessite occurs as grains up to $0.15 \mathrm{~mm}$ in size in assemblages with native gold, coloradoite (Fig. 7E), and petzite, as well as individual grains in quartz and carbonate in the Australia East \#3 Eastern caunter lode, the

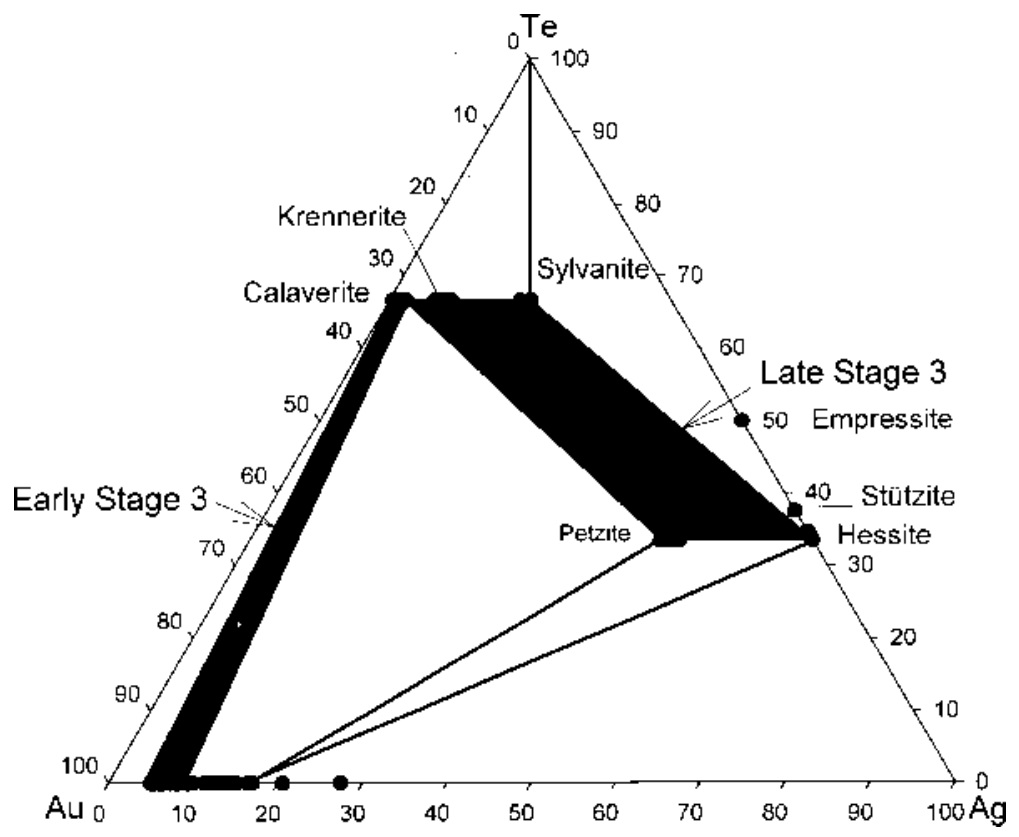

FIG. 8. Plot showing phase relations among precious metal tellurides and native elements in the Golden Mile deposit, in terms of the system $\mathrm{Au}-\mathrm{Ag}-\mathrm{Te}$. The early gold-rich assemblage preceded deposition of the more silver-rich assemblages. 
Boulder Western Main lode, and the Oratava lode. However, it was also documented at several other locations in association with native gold (Baker 1958), sylvanite (Stillwell 1953, Baker 1958, Markham 1960, Travis 1966), altaite (Stillwell 1931, Baker 1958, Golding 1978), coloradoite (Travis 1966) and tetradymite (Markham 1960). Electron-microprobe analyses obtained here show that hessite contains up to $1.1 \mathrm{wt} \%$ $\mathrm{Au}$; Markham (1960) reported hessite with up to 0.8 wt.\% Au.

Stützite is rare in the Golden Mile and was not found during the present study. It was reported previously to have formed in contact with krennerite (Golding 1978), sylvanite (Markham 1960) and tellurantimony (Golding 1978), and as veins cross-cutting pyrite and hessite (Stillwell 1931). Golding reported that stützite contains a small amount of gold.

Melonite, $1.2 \mathrm{~mm}$ in size, was observed in the present study in carbonate coexisting with coloradoite (Fig. 7F). Earlier investigators observed melonite in contact with calaverite (Stillwell 1931, Markham 1960, Travis 1966), montbrayite (Travis 1966), krennerite (Stillwell 1931, Travis 1966), petzite (Markham 1960, Travis 1966) and altaite (Markham 1960).

Unnamed Ni-rich telluride $\left(\mathrm{Ni}_{2} \mathrm{Te}_{3}\right)$ was reported by Scantlebury (1983) in the 809/1 lode. It contains up to 23.5 wt.\% Ni, but has not been identified in any other study.

Tetradymite was first identified by Simpson (1912) and later by Markham (1960), who documented it in contact with petzite, sylvanite, hessite, calaverite, coloradoite and native gold.

Nagyágite was not observed in the present study, but has been reported in contact with krennerite (Markham 1960), coloradoite (Stillwell 1953, Markham 1960) and petzite (Stillwell 1931, Markham 1960). A sample analyzed by Simpson (1912) was found to contain $1.1 \mathrm{wt} . \%$ Ag.

Weissite was not identified during the present study. However, previous investigators identified it in contact with coloradoite (Baker 1958), krennerite (Stillwell 1931, Markham 1960) and sylvanite (Stillwell 1931). Weissite seems to be restricted to the supergene stage of mineralization. It has been recorded in samples containing secondary chalcocite and covellite (Markham 1960).

Tellurantimony was observed in our study in four samples in the Oroya, B Eastern Main lode, and No. 4 Western Main lode, where it occurs in contact with petzite, native gold, and altaite. It had previously been reported to coexist with calaverite (Stokes 1989), coloradoite, stützite, and native tellurium (Travis 1966).

Au-As telluride, an unnamed mineral, was described by Travis (1966) in two samples coexisting with calaverite, petzite, coloradoite, bornite and tetrahedrite. The mineral is pale bluish gray in color and anisotropic. Owing to a lack of a suitable As standard, Travis (1966) was unable to determine the exact composition of the mineral, although he was able to show that it was dominated by $\mathrm{Au}, \mathrm{As}$ and $\mathrm{Te}$ and a minor amount of $\mathrm{Pb}$.

Mattagamite and frohbergite were identified in one sample south of the Golden Mile (Golding 1978). They occur in contact with pyrrhotite, calaverite, montbrayite and native gold.

Native tellurium is rare in the Golden Mile deposit and was first identified by MacIvor (1899). Markham (1960) reported its presence in the Tetley lode in contact with sylvanite. Travis (1966) documented it in the Boulder lode as a replacement of tellurantimony, whereas Scantlebury (1983) observed native tellurium in the Blatchford lode as grains 0.1 to $2 \mathrm{~mm}$ long that seem to have replaced altaite.

\section{DisCUSSION}

\section{Telluride-bearing assemblages}

Unlike their epizonal counterparts, which may contain a diversity of tellurides (e.g., Spry et al. 1997), mesozonal gold deposits are normally characterized by a relatively simple array of tellurides. The Golden Mile deposit thus appears to be unique owing to the abundance and variety of tellurides. The most common telluride contact assemblages in the Golden Mile are coloradoite - petzite, calaverite - coloradoite, altaite hessite, calaverite - native gold, calaverite - petzite and hessite - sylvanite. Less common contact-assemblages include altaite - montbrayite, altaite - petzite, calaverite - krennerite, calaverite - melonite, coloradoite - native gold, coloradoite - krennerite, native gold - petzite, native gold - tellurantimony, hessite - petzite and altaite - montbrayite - petzite. Although these are the most common assemblages reported in the Golden Mile, eighty-eight different assemblages of tellurides have been documented (Table 4).

Contact assemblages in the system $\mathrm{Au}-\mathrm{Ag}-\mathrm{Te}$ that have been identified in the Golden Mile are shown in Figure 8 . This diagram serves to support textural studies suggesting that at least two generations of telluride mineralization formed in Fimiston-style lodes during stage 3 . The assemblages shown in Table 4 and schematically represented in Figure 8 are those reported at room temperature and do not necessarily represent the assemblages at ore-forming conditions. The assemblages hessite - sylvanite and sylvanite - petzite are likely to be products of the solid-state breakdown of the $\gamma$-phase or $\chi$-phase below $120^{\circ} \mathrm{C}$ from the following assemblages: stützite $+\gamma$-phase, $\gamma$-phase or $\chi$-phase, or stützite + sylvanite $+\gamma$-phase (Cabri 1965). On the basis of the experimental studies of Cabri (1965), the assemblage petzite - hessite must have formed from the breakdown of the $\chi$-phase below $50 \pm 20^{\circ} \mathrm{C}$. The assemblage krennerite - stützite, which was reported by Golding (1978), is problematic, as it has never been established in any experimental studies. 


\section{Distribution of metallic minerals}

Golding (1978) claimed that tetrahedrite-group minerals, native gold and montbrayite are spatially zoned in the Golden Mile. Golding suggested that tetrahedritegroup minerals are present in the Western lodes, with the $\mathrm{Sb}-\mathrm{Ag}-\mathrm{Zn}$-rich members being found at depth, and the As-Fe-rich members occurring closer to the surface.

TABLE 4 TELLURIDE AND NATIVE ELEMENT CONTACT-ASSEMBLAGES DOCUMENTED FOR THE GOLDEN MILE DEPOSIT

\begin{tabular}{|c|c|c|c|}
\hline 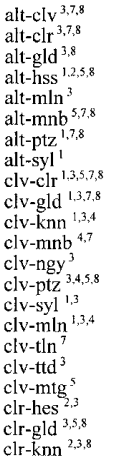 & 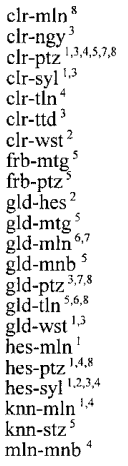 & 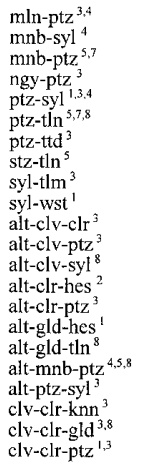 & 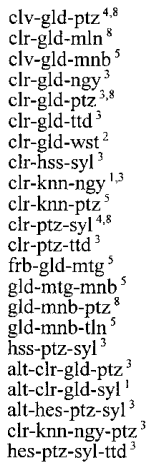 \\
\hline
\end{tabular}

Symbols: alt: altaite, clv: calaverite, clr: coloradoite, frb: frohbergite, gld: native gold, hes: hessite, knn: krennerite, mtg: mattagamite, mln: melonite, mnb: montbrayite, ngy: nagyágite, ptz: petzite, stz: stützite, syl: sylvanite, tlm: native tellurium, th: tellurantimony, ttd: tetradymite, wst. weissite. References: 1 Stillwell (1931), 2 Baker 7 Stokes (1983), 8 this study.
However, if her data are combined with ours, no vertical variations in the composition of tetrahedrite-group minerals in the Western lodes are apparent. Furthermore, such a vertical zonation from the Eastern lode system also was not observed. On the contrary, As-rich and As-poor members were both identified at depths ranging from 100 to $>600 \mathrm{~m}$ below the surface. A lateral variation in the composition of tetrahedrite-group minerals also is absent.

On the basis of values obtained in the present study and those reported by Golding (1978), there appears to be a decrease in gold fineness values with depth. High values (up to 971) were found in material as shallow as $65 \mathrm{~m}$ below the surface of the deposit, whereas more Ag-rich gold grains (fineness values as low as 901) seem restricted to much greater depths (400 to $675 \mathrm{~m}$ below the surface). A plot of average values versus depth for twenty-four samples analyzed during the present study illustrates a weak to moderate positive correlation of 0.48 (Fig. 9). Note that Figure 9 does not include the presence of one outlier, a gold grain with a fineness of 972, which was found $355 \mathrm{~m}$ below the surface. According to Gammons \& Williams-Jones (1995), many factors control the composition of gold-silver alloy in ore deposits, including temperature, activities of $\mathrm{S}_{2}$ and $\mathrm{O}_{2}$, concentration of $\mathrm{Cl}^{-}, \mathrm{pH}$ and total $\mathrm{Au} / \mathrm{Ag}$ content of the hydrothermal fluid. It is unclear whether one or more of these parameters systematically varied during the deposition of the gold ore at the Golden Mile. We speculate that the vertical variation in fineness values likely reflect changes in several of these parameters that result

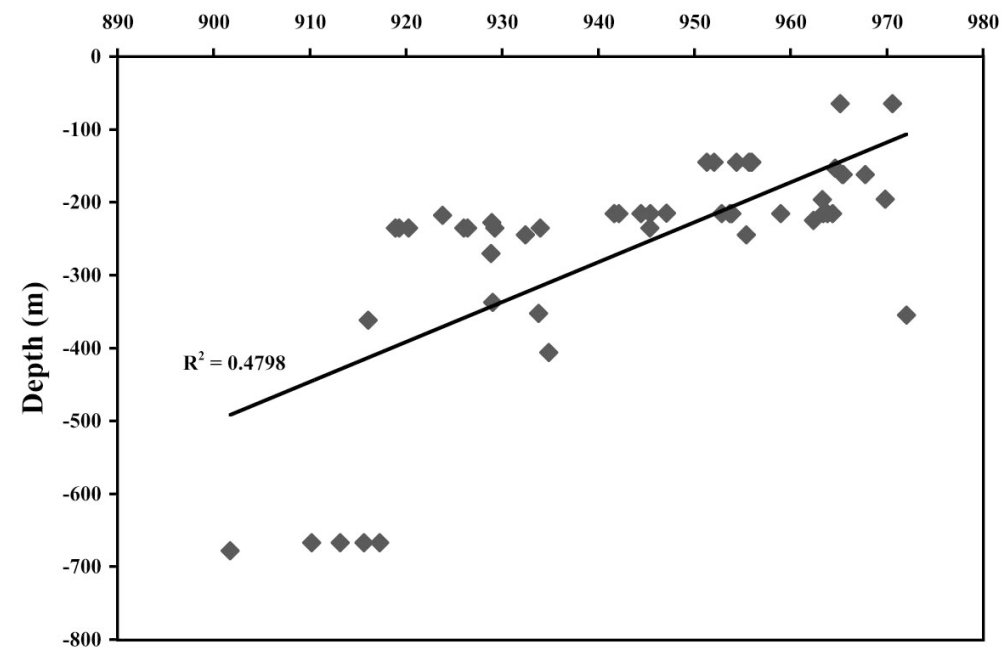

Gold Fineness

FIG. 9. Gold fineness versus depth. Points represent average values of gold fineness in individual samples. 
from the complex evolution of the ore-forming fluid (Phillips et al. 1996, Bateman et al. 2001b).

Golding (1978) reported that montbrayite is restricted to the edges of the Golden Mile. However, this observation was based on the location of only three montbrayite-bearing samples. Whether any lateral or vertical variation in the distribution of montbrayite exists remains uncertain owing to the paucity of samples. However, it should be noted that we identified montbrayite in the No. 2 Western lode, which is located near the middle of the deposit. The combination of samples utilized in the present study with those collected by Golding (1978) strongly suggests that there is no lateral or vertical variation in the distribution of any tellurides, including montbrayite (Figs. 10A, B, C, D).

The lack of compositional variation in the distribution of tellurides at the mine scale is largely reflected by the heterogeneity of tellurides within and between lodes. Such heterogeneities can occur in two adjacent samples in a given lode. Furthermore, we have been unable to detect systematic differences in composition between Western and Eastern lodes.

\section{Conditions and mechanisms of telluride deposition}

Estimates of the temperature of ore formation of the Golden Mile are equivocal and are based primarily on fluid-inclusion studies of Ho (1987), Clout (1989), and Ho et al. (1990), and on chlorite (Phillips \& Gibb 1993), sulfur isotope (Golding \& Wilson 1983) and calciteankerite (Phillips \& Brown 1987) geothermometry.

Homogenization temperatures $\left(\mathrm{ca} .110^{\circ}\right.$ to $\left.250^{\circ} \mathrm{C}\right)$ with most in the range $170^{\circ}$ to $250^{\circ} \mathrm{C}$, were reported by Clout (1989) for Fimiston-style gold veins. Salinities were found to vary from 0 to $13 \mathrm{wt} . \% \mathrm{NaCl}$ eq. The presence of coexisting $\mathrm{CO}_{2}$-rich $\left(\mathrm{H}_{2} \mathrm{O}\right.$-poor) and mixed aqueous-carbonic inclusions suggested to Clout that these fluids had undergone phase separation. Ho (1987)
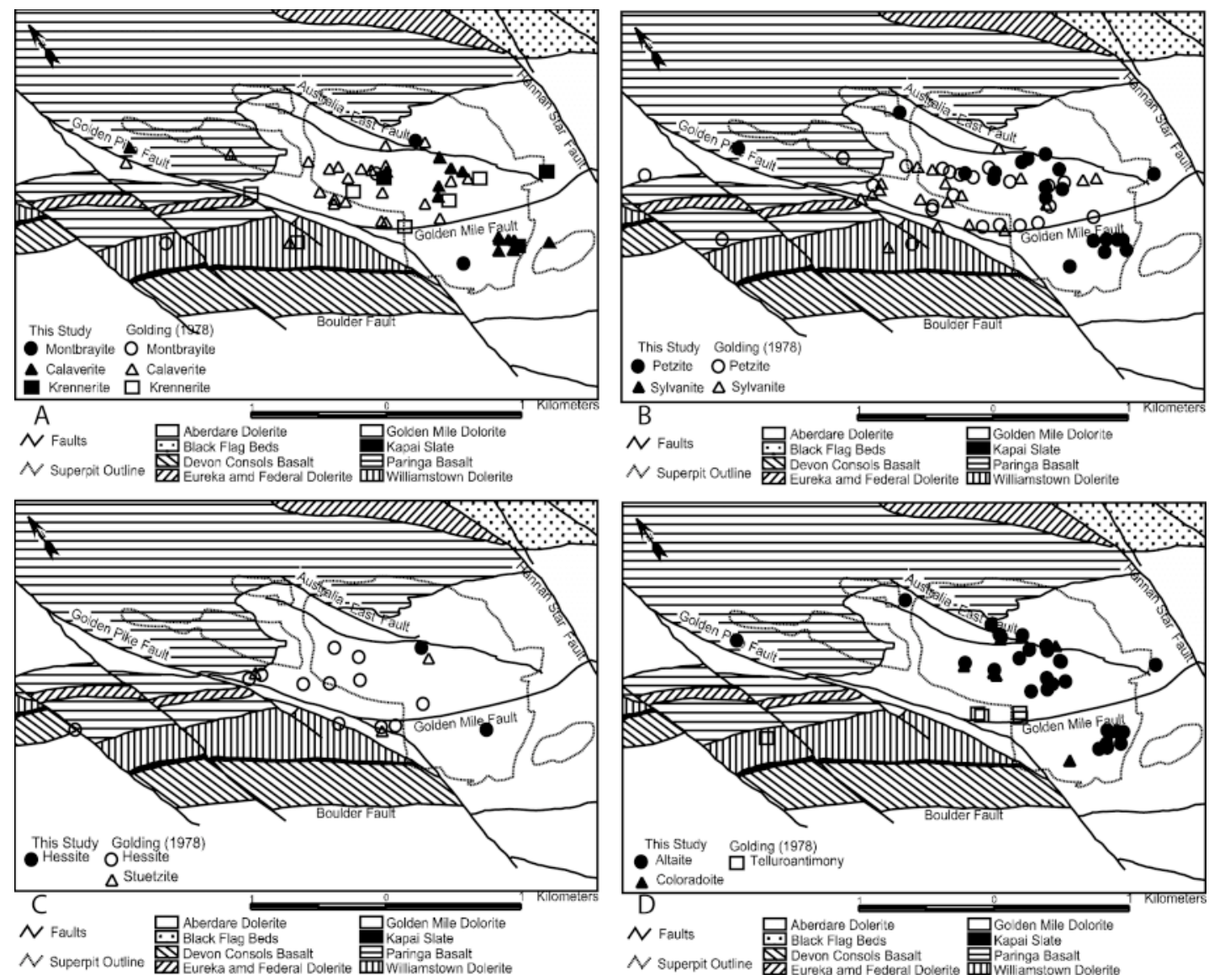

FIG. 10. Maps of the Golden Mile deposit illustrating the location of: (A) calaverite, montbrayite and krennerite, (B) petzite and sylvanite, (C) hessite and stützite, (D) altaite, coloradoite and tellurantimony. Data are from Golding (1978) and this study. 
and Ho et al. (1990) reported that fluid inclusions in type-2 and type-3 Fimiston-style ores from the Lake View lode are three-phase aqueous-carbonic fluids that homogenized between $160^{\circ}$ and $240^{\circ} \mathrm{C}$. In contrast to Clout (1989), who reported a wide range of salinities and $\mathrm{CO}_{2}$ contents for Fimiston-style ore fluids, Ho et al. (1990) suggested that these fluids contained 15-20 mole \% $\mathrm{CO}_{2}$ and $<5.5$ wt. $\% \mathrm{NaCl}$ eq.

According to Clout (1989), Oroya-style mineralization was deposited at $170^{\circ}$ to $220^{\circ} \mathrm{C}$. This range of temperatures is significantly lower than the $225^{\circ}$ to $355^{\circ} \mathrm{C}$ reported by Ho (1987) and Ho et al. (1990), who also noted that Oroya-style fluids were $\mathrm{H}_{2} \mathrm{O}-\mathrm{CO}_{2}-\mathrm{CH}_{4}$-bearing and of low salinity ( $<5 \mathrm{wt} . \% \mathrm{NaCl}$ eq.).

Ho et al. (1990) concluded that Fimiston-style gold was deposited at 1.5 to $4 \mathrm{kbar}$ and $280^{\circ}-330^{\circ} \mathrm{C}$, after correcting the homogenization temperatures for pressure. This temperature range is in agreement with that obtained by Golding \& Wilson (1983) from sulfur isotope data $\left(250^{\circ} \pm 50^{\circ} \mathrm{C}\right)$ and by Phillips \& Brown (1987) using the calcite-ankerite geothermometer $\left(330^{\circ} \pm\right.$ $40^{\circ} \mathrm{C}$ ). Although it is unclear whether any of the samples used by Golding \& Wilson and Phillips \& Brown were related to the deposition of tellurides, it should be noted that Phillips et al. (1996) considered the gold to have deposited at $300^{\circ} \mathrm{C}$, approximately.

Paragenetic studies of Fimiston-style mineralization demonstrate that there are at least two stages of telluride deposition in stage 3 , an earlier calaverite-rich assemblage followed by a stage characterized by more silver-rich tellurides (krennerite, petzite, sylvanite and hessite; stützite may have formed even later). On the basis of the geothermometric studies for stage- 3 mineralization discussed above, it is likely that the maximum temperature of telluride deposition was about $300^{\circ} \mathrm{C}$. This temperature matches well a maximum temperature of $290^{\circ} \mathrm{C}$ for the stability of the assemblage sylvanite calaverite (Kelly \& Goddard 1969). The fluid-inclusion studies of Clout (1989) suggest a lower limit of approximately $170^{\circ} \mathrm{C}$ for Fimiston-style (telluride-bearing) mineralization. However, the assemblages petzite - sylvanite and sylvanite - hessite formed below $170^{\circ} \mathrm{C}$ from reactions involving the $\gamma$-phase or the $\chi$-phase (Cabri 1965).

On the basis of the mineral parageneses observed for the early gold-rich stage (assuming a maximum $\mathrm{T}$ of $300^{\circ} \mathrm{C}$ ) and experimental data for pyrite, calaverite, native gold, chalcopyrite and coloradoite given in Afifi et al. (1988), we infer values of $\log f\left(\mathrm{Te}_{2}\right)$ between -11.4 and -6.8 and $\log f\left(\mathrm{~S}_{2}\right)$ between -12.6 and -5.5 for Fimiston-style ores (Fig. 11A); although below the lower temperature-limit of approximately $170^{\circ} \mathrm{C}$ for Fimiston-style ore, we determined values of $\log f\left(\mathrm{~S}_{2}\right)$ between -24.9 and -9.5 and $\log f\left(\mathrm{Te}_{2}\right)$ between -26.2 and -14.1 at $100^{\circ} \mathrm{C}$ for the late $\mathrm{Ag}$-rich mineralization, on the basis of equilibrium assemblages involving hessite, stützite, coloradoite, frohbergite and pyrrhotite (Fig. 11B).
Origin of the Golden Mile and its relationship to the deposition of tellurides

The origin of the Golden Mile is steeped in controversy and is based on several disparate genetic models. Reviews of the more realistic models are summarized by Phillips et al. (1996) and Bateman et al. (2001b), for example, and will not be repeated here. They include exhalative (e.g., Tomich 1974), magmatic-epithermal (Clout 1989), and metamorphic-replacement models (e.g., Groves \& Phillips 1987).

There is a high proportion of precious-metal tellurides and intimately associated vanadium-bearing minerals in the Golden Mile. Although this association is unusual for a deposit generally regarded as mesozonal, it is not unique, since tellurides and vanadium-bearing minerals occur in the Mother Lode, California (Weir \& Kerrich 1987) and Hemlo, Ontario (Harris 1989). Such minerals are considerably more common in epizonal ores, in which $\mathrm{Au}, \mathrm{Te}$, and $\mathrm{V}$ are generally ascribed to an alkaline igneous source. Clout (1989) utilized this association of elements, highly variable salinities of fluids, and $\mathrm{O}$ and $\mathrm{H}$ isotope compositions to support an epizonal origin for the Golden Mile. However, there are several problems with the epizonal model, including the high values of gold fineness, and the carbonic nature of the ore fluids, which are more characteristic of mesozonal ores. Despite these concerns, the fact remains that temperatures of fluid-inclusion homogenization for Fimiston- and Oroya-style mineralization primarily range from $170^{\circ}$ to $300^{\circ} \mathrm{C}$ and suggest that they formed near the epizonal-mesozonal transition.

Cooke \& McPhail (2001) used the computer program CHILLER (Reed 1982) to numerically model mechanisms of telluride deposition in the epithermal Acupan gold-silver telluride deposit in the Philippines. Their modeling allowed them to evaluate the relative importance of processes such as boiling, fluid mixing, cooling, pressure throttling, wallrock interaction, and condensation over the temperature range $150^{\circ}$ to $300^{\circ} \mathrm{C}$. Using input parameters based on fluid inclusion and stable isotope studies, Cooke \& McPhail surmised that the Acupan ores formed from dilute $(c a .0 .5 \mathrm{wt} . \% \mathrm{NaCl}$ eq.), $\mathrm{CO}_{2}$-bearing meteoric fluids $\left(0.41 \mathrm{~m} \mathrm{CO}_{2}\right)$ at about $200^{\circ}$ to $300^{\circ} \mathrm{C}$. With tellurium concentrations in the fluid as low as 0.005 to 5 ppt, Cooke \& McPhail (2001) proposed that $\mathrm{Te}$ is transported in the vapor phase rather than the aqueous phase, and that condensation of $\mathrm{Te}_{2(\mathrm{~g})}$ and $\mathrm{H}_{2} \mathrm{Te}_{(\mathrm{g})}$ into precious metal brines is the only viable mechanism for depositing telluride ores. If the Golden Mile is an epizonal deposit, as claimed by Clout (1989), there are several physicochemical constraints for the Golden Mile that are quite different from those that formed the Acupan deposit. For example, the ore fluids that formed the Golden Mile deposit are at least an order of magnitude more saline and carbonic than those that formed the Acupan deposit, even though these two parameters will not affect aqueous tellurium solubili- 

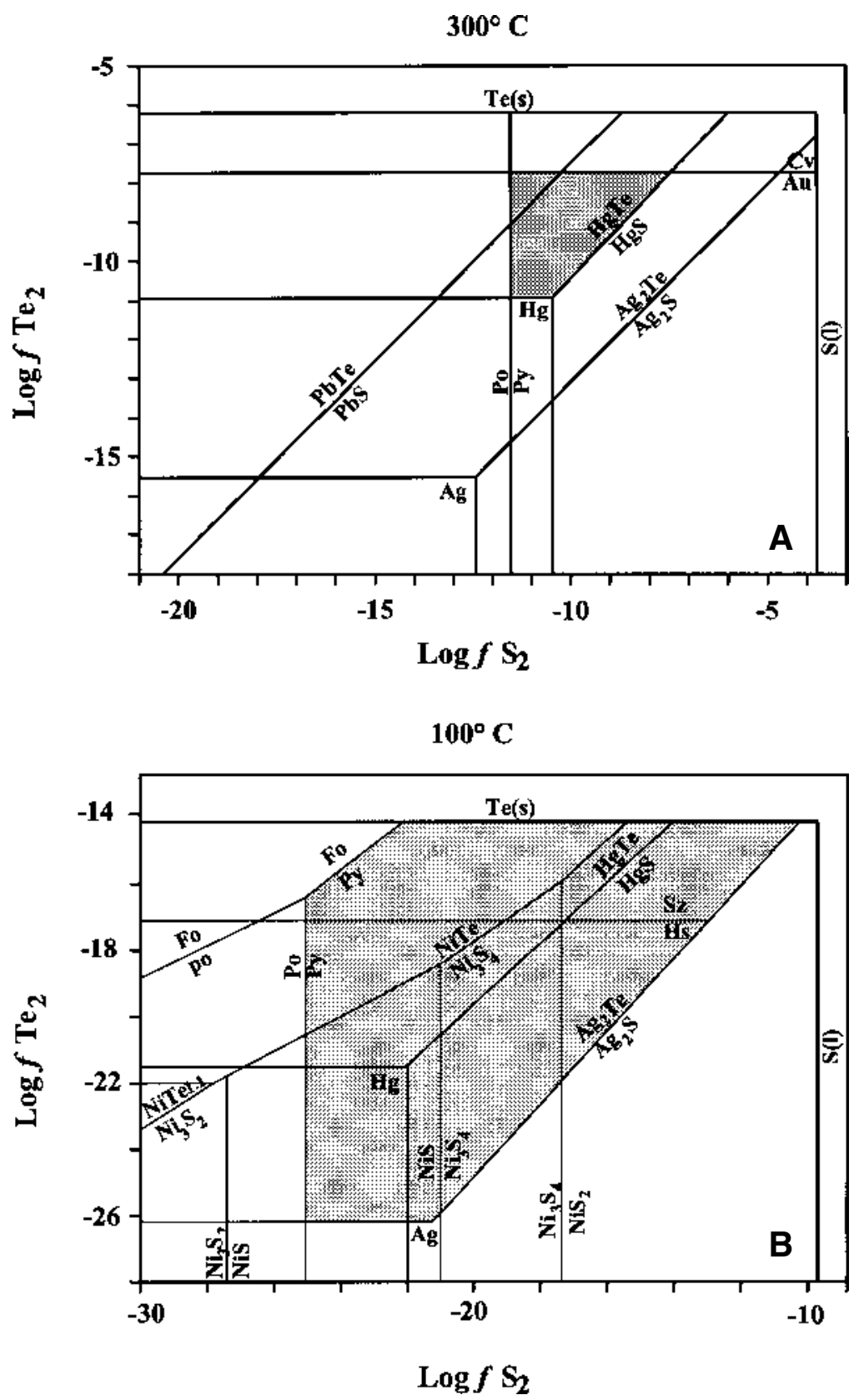

FIG. 11. The stabilities of sulfides and tellurides in the Golden Mile deposit as a function of $f\left(\mathrm{~S}_{2}\right)$ and $f\left(\mathrm{Te}_{2}\right)$. (A) Early stage 3 (shaded area), (B) late stage 3 (shaded area). Although petzite - sylvanite and sylvanite - hessite formed below $170^{\circ} \mathrm{C}$ from reactions involving $\gamma$-phase or $\chi$-phase (Cabri 1965), only the stability of hessite is shown here in view of the thermodynamic data available. Equilibria were calculated at $100^{\circ} \mathrm{C}$ using data listed in Afifi et al. (1988). 
ties. Furthermore, given the input parameters used by Cooke \& McPhail (2001) for the Acupan deposit, their modeling predicts that hessite would precipitate at temperatures $>270^{\circ} \mathrm{C}$, whereas calaverite would precipitate after hessite below $<250^{\circ} \mathrm{C}$. This is contrary to what is observed in the Golden Mile deposit. Mineralogical, paragenetic, and fluid-inclusion studies suggest that calaverite precipitated close to $300^{\circ} \mathrm{C}$, followed by hessite and gold-silver telluride deposition at temperatures close to or $<170^{\circ} \mathrm{C}$. However, the order of precipitation of the precious metal tellurides will vary depending upon the $\mathrm{Au}: \mathrm{Ag}$ ratio of these metals in the ore-forming fluid.

The spatial relationship between high-grade telluride zones and lode intersections as well as high-grade telluride zones and lode-shear intersections in the Golden Mile may be the result of throttling (i.e., periodic release of gas from a solution due to sudden changes in pressure at, for example, a pinch-and-swell structure in a vein). However, fluid-inclusion studies suggest that gold deposition (including the tellurides) accompanied effervescence. The tellurides thus formed locally by the condensation of tellurium-bearing species from the vapor phase, as is consistent with the general behavior of telluride formation elsewhere (e.g., Cooke \& McPhail 2001). Walshe et al. (2003) recognized the solubility studies of Cooke \& McPhail (2001), and advocated that tellurides in the Golden Mile deposit were formed by condensing oxidized magmatic tellurium-rich vapors into reduced gold-rich fluids.

It is uncertain whether tellurides were deposited by cooling or through fluid interactions with the wallrocks at other locations in the Golden Mile deposit. However, in this context, note that whereas pervasive alteration extends for several kilometers, tellurides are more abundant in inner haloes of alteration adjacent to the lodes

\begin{tabular}{|c|c|c|c|c|}
\hline Rock Unit & Au ppb & Ag ppb & Te ppb & V ppm \\
\hline \multicolumn{5}{|l|}{ Hannans Lake Serpentinite } \\
\hline less altered & $0.48-3.00$ & 45 & 15 & 120 \\
\hline more altered & $16-87$ & 12 & 220 & 120 \\
\hline Williamstown Dolerite & $1.7-7.7$ & - & - & $180-200$ \\
\hline Devon Consols Basalt & $1.4-0.68$ & - & - & 270 \\
\hline Paringa Basalt & $0.71-1.4$ & $35-40$ & $33-41$ & $250-490$ \\
\hline Golden Mile Dolerite & $0.15-1.5$ & $10-115$ & $3-50$ & 840 \\
\hline \multicolumn{5}{|l|}{ Interflow Sedimentary Rocks } \\
\hline $\begin{array}{l}\text { in the Paringa Basalt } \\
\text { between the Paringa Basalt }\end{array}$ & $16-420$ & $340-1200$ & $380-4100$ & $40-100$ \\
\hline and the Golden Mile Dolerite & 25 & 360 & 260 & 40 \\
\hline Kapai Slate & 39 & 2900 & 2000 & $<50$ \\
\hline \multicolumn{5}{|l|}{$\begin{array}{l}\text { Black Flag Beds } \\
\text { sedimentary rocks other }\end{array}$} \\
\hline Black pyritic shales & $12-49$ & $150-2900$ & $240-3600$ & $40-200$ \\
\hline
\end{tabular}

* after Golding (1978) than in distal haloes (Bateman et al. 2001b), which suggests that wallrock interactions may have been important in contributing to the deposition of tellurides. Recent calculations of fluid-rock buffering by White $e t$ al. (2003) indicate that metamorphic assemblages in the alteration halo are consistent with interaction of a single composition of metamorphic fluid with the host rocks and that the zoned alteration-induced halo around gold lodes reflects the volume of the fluid with which the rocks reacted.

Recent laser-based sulfur isotope studies of pyrite from Fimiston- and Oroya-style mineralization by Hagemann et al. (1999) revealed a distinct isotopic zonation at the deposit and grain scales. This zonation apparently resulted from several mechanisms of deposition such as phase separation and fluid mixing from igneous and sedimentary sources, which were tapped during the protracted hydrothermal history of the Golden Mile. Fluid modeling using CHILLER has shown that native gold (e.g., Reed \& Spycher 1985) and precious-metal tellurides (e.g., Cooke \& McPhail 2001) in epithermal gold deposits can form by a variety of mechanisms in different parts of a given deposit. Such a variety of mechanisms may also be responsible for the precipitation of precious metals at the Golden Mile and may explain the heterogeneity of tellurides within a given lode and the absence of a systematic distribution of tellurides throughout the large Golden Mile mineralizing system.

\section{Sources of $A u, A g, T e$, and $V$}

In addition to conflicts concerning the origin and the mechanisms for depositing gold-telluride mineralization in the Golden Mile, arguments have arisen concerning the sources of the ore fluids and various ore-bearing components, such as $\mathrm{Au}, \mathrm{Ag}, \mathrm{Te}$, and V. Proposed sources of metal include the supracrustal greenstones (Larcombe 1912, Groves 1993), felsic magmas (e.g., Gustafson \& Miller 1937), the Golden Mile dolerite (Tomich 1974, Golding 1978), alkaline igneous rocks (Clout 1989), and the Black Flag metasedimentary rocks (Golding 1978). Golding (1978) obtained trace-element data from the Hannans Lake Serpentinite, Williamstown peridotite, Devon Consols Basalt, Paringa Basalt, Golden Mile gabbro, Black Flag Beds and interflow sedimentary rocks in the Kalgoorlie succession, using the most weakly altered samples available. She found that none of the lower mafic and ultramafic rock units (Hannans Lake Serpentinite, Devon Consols Basalt, Paringa Basalt, Williamstown peridotite, Devon Consols Dolerite and Golden Mile gabbro) are enriched in $\mathrm{Au}, \mathrm{Ag}$ or Te (Table 5) relative to typical mafic and ultramafic rocks, whereas both the interflow sedimentary rocks and Black Flag Beds showed significant enrichment with respect to $\mathrm{Au}, \mathrm{Ag}$, and Te. Thus, Golding (1978) proposed that these elements might have been derived from black shales in the Black Flag Beds or 
from the interflow sedimentary rocks. However, it is also possible that Black Flag Beds simply acted as a chemical trap for $\mathrm{Au}, \mathrm{Ag}$, and $\mathrm{Te}$.

Recent studies by Bateman et al. (2001a) determined the $\mathrm{V}$ content of several mafic and ultramafic rocks in the vicinity of the Golden Mile deposit, including the Eureka gabbro (234-444 ppm, $\overline{\mathrm{x}}=308 \mathrm{ppm})$, Aberdare gabbro (335-405 ppm, $\overline{\mathrm{x}}=368 \mathrm{ppm}$ ), Golden Mile gabbro (38-722 ppm, $\bar{x}=296$ ppm), Black Flags basalt (287-526 ppm, $\overline{\mathrm{x}}=375 \mathrm{ppm})$, Paringa basalt (230-441 ppm, $\bar{x}=332$ ppm) and the Devon Consols basalt (382$441 \mathrm{ppm}, \overline{\mathrm{x}}=270 \mathrm{ppm}$ ). There appears to be little difference in $\mathrm{V}$ contents among the ultramafic and mafic rocks, except that the highest $\mathrm{V}$ content was obtained from a fine-grained sample of Golden Mile gabbro. The high V content of the Golden Mile gabbro is supported by the trace-element data of Travis (1966) and Golding (1978).

Although the alkaline igneous rocks (e.g., lamprophyres) mentioned by Clout (1989) might have been a source of $\mathrm{Au}, \mathrm{Te}$ and $\mathrm{V}$, it is unlikely that they were volumetrically abundant enough to provide all of the gold in the Golden Mile deposit. Recent genetic models for the formation of the Golden Mile deposit by Phillips et al. (1996) and Bateman et al. (2001b) emphasize a "protracted gold mineralization model" in which there is probably no unique source for the ore-forming fluids and no single mechanism for the deposition of the ore. Phillips et al. (1996) and Bateman et al. (2001b) pointed out that the period of time over which gold mineralization was deposited ( $c a .50 \mathrm{Ma}$ ) and the complex interplay of a variety of favorable factors (e.g., host-rock compositions, mechanical properties of certain rocks, structural disposition, fluid composition and focusing) were the main causes for the huge size of the Golden Mile.

Although there appears to be sufficient Au, Ag, V, and Te in the Kalgoorlie Succession to account for the amounts of these elements in the Golden Mile, their source(s) remains uncertain. Walshe et al. (2003) proposed that gold mineralization in the Eastern Goldfields Province of the Yilgarn Craton, including the Golden Mile deposit, resulted from reaction between two distinct fluid systems. They proposed that oxidized magmatic hydrothermal brines and vapors (including vapors of Te and V), originated in mafic and syenitic-granitic magmas, and reacted with reduced fluids composed primarily of $\mathrm{H}_{2}-\mathrm{H}_{2} \mathrm{~S} \pm \mathrm{CH}_{4}$ derived from the deep crust or mantle. Regardless of the nature and source of the ore-forming fluid, it seems that the Mount-Charlottestyle mineralization is a separate gold-forming event more typical of other lode-gold deposits in the Yilgarn Craton and that it overprinted Fimiston- and Oroyastyles of mineralization.

To form a deposit as large as the Golden Mile, the fluid-flow regime would have been enormous and fluids would likely have interacted with a large volume of different rocks, on the path to the site of deposition.
These rocks likely included those in the Kalgoorlie Succession as well as deeper source-rocks through which the ore-forming fluids flowed.

\section{Conclusions}

1. Tellurides account for $c a .20 \%$ of the gold content of the Golden Mile deposit and are a very important source of gold. Although nineteen tellurium-bearing minerals have been identified, the most abundant precious-metal telluride is calaverite, followed by petzite, whereas the most common non-precious metal telluride is coloradoite.

2. The paragenetic sequence of Fimiston-style ores can be divided into three distinct hydrothermal stages, with the third stage being divided into at least two substages, an early gold-rich telluride-bearing substage followed by a later silver-rich telluride-bearing substage. The temperature of formation of the telluride ore is $<300^{\circ} \mathrm{C}$, with some of the Ag-bearing tellurides forming at $<170^{\circ} \mathrm{C}$, on the basis of upper stability-limit of petzite - sylvanite and sylvanite - hessite. The upper limit of $300^{\circ} \mathrm{C}$ is the same as that proposed by Phillips et al. (1996) based on studies of fluid inclusions (Ho et al. 1990), stable isotopes (Golding et al. 1990) and alteration assemblages.

3. The approximate field of stability for the goldrich early-stage Fimiston ores is $\log f\left(\mathrm{Te}_{2}\right)$ in the range -11.4 to -6.8 and $\log f\left(\mathrm{~S}_{2}\right)$ in the range -12.6 to -5.5 $\left(300^{\circ} \mathrm{C}\right)$, whereas the stability field for the later silverrich stage ores is $\log f\left(\mathrm{~S}_{2}\right)$ in the range -24.9 to -9.5 and $\log f\left(\mathrm{Te}_{2}\right)$ in the range -26.2 to $-14.1\left(100^{\circ} \mathrm{C}\right)$.

4. Native gold in the Golden Mile deposit is goldrich, with fineness values ranging from 901 to 972 . These values appear to decrease systematically with depth. Despite earlier suggestions by Golding (1978), for example, that metallic minerals such as tellurides (montbrayite and tellurantimony) and tetrahedrite-group minerals may be zoned either laterally or vertically, there is no evidence for zoning of these minerals or any telluride in the Golden Mile deposit. Furthermore, tellurides have a heterogeneous distribution in and between lodes.

5. The source of the ore-forming components, such as $\mathrm{Au}, \mathrm{Ag}, \mathrm{V}$, and $\mathrm{Te}$, and the mechanisms of telluride precipitation remain unclear. However, owing to the enormity of the Golden Mile deposit, the complex interplay of physicochemical conditions and the huge volume of auriferous fluid required to form the gold mineralization, no single source is likely and no single mechanism resulted in gold-telluride deposition. On the contrary, tellurides were probably deposited by several mechanisms (phase separation, wallrock interaction, cooling, and possibly condensation and fluid mixing). Multiple mechanisms likely account for the heterogeneous distribution of tellurides in the deposit. Elements such as $\mathrm{Au}, \mathrm{Ag}, \mathrm{V}$, and Te are not necessarily required to have been derived from shallow alkaline igneous 
rocks, similar to those associated with epizonal goldtelluride deposits; rather, these elements were likely scavenged from a variety of mafic and ultramafic rocks in the vicinity of the Golden Mile as deeply derived ore fluids likely interacted with a wide variety of rock types, including those in the Kalgoorlie Succession.

\section{ACKNOWLEDGEMENTS}

The authors thank Kalgoorlie Consolidated Gold Mines for financially supporting this project. Discussions with Chris Heath, Neil Phillips and Cam McCuaig concerning the distribution of tellurides in the Golden Mile and the structure of the deposit, respectively, are also greatly appreciated. Finally, we thank Cinzia Cervato, David Cooke, William C. Kelly, Robert F. Martin, and Bob Seal for their comments on the manuscript.

\section{REFERENCES}

Afifi, A.M., Kelly, W.C. \& Essene, E.J. (1988): Phase relations among tellurides, sulfides, and oxides. I. Thermochemical data and calculated equilibria. Econ. Geol. 83, 377-394.

BAKer, G. (1958): Tellurides and selenides in the Phantom Lodes, Great Boulder gold mine, Kalgoorlie. Austral. Inst. Mining Metall., Stillwell Anniv. Vol., 15-40.

Bateman, R. (1998): Laser Microprobe Analyses of Pyrite from a Flotation Concentrate. Unpubl. Rep., Kalgoorlie Consolidated Gold Mines.

Costa, S., Swe, T. \& Lambert, D. (2001a): Archaean mafic magmatism in the Kalgoorlie area of the Yilgarn Craton, Western Australia: a geochemical and Nd isotopic study of the petrogenetic and tectonic evolution of a greenstone belt. Precamb. Res. 108, 75-112.

Hagemann, S., McCuaig, C. \& Swager, C. (2001b): Protracted gold mineralization throughout Archaean orogenesis in the Kalgoorlie camp, Yilgarn Craton, Western Australia: structural, mineralogical, and geochemical evolution. In World-class Gold Camps and Deposits in the Eastern Yilgarn Craton, Western Australia, with Special Emphasis on the Eastern Goldfields Province (S.G. Hagemann, P. Neumayr \& W.K. Witt, eds.). Western Australia Geol. Surv., Record 2001/17 (63-98).

CABRI, L.J. (1965): Phase relations in the $\mathrm{Au}-\mathrm{Ag}-\mathrm{Te}$ system and their mineralogical significance. Econ. Geol. 60, 15691606.

Chryssoulis, S. (1998): Ion Probe Analysis of Fimiston Pyrites. Unpubl. Rep., Kalgoorlie Consolidated Gold Company.

CLout, J.M.F. (1989): Structural and Isotopic Studies of the Golden Mile Gold-Telluride Deposit, Kalgoorlie, Western Australia. Ph.D. thesis, Monash Univ, Clayton, Australia.
Cleghorn, J.H. \& EAton, P.C. (1990): Geology of the Kalgoorlie gold field. In Geology of the Mineral Deposits of Australia and Papua New Guinea (F.E. Hughes, ed.). Austral. Inst. Mining Metall., Melbourne, Australia (411-431).

Cook, N.J. \& Chryssoulis, S.L. (1990): Concentrations of "invisible gold" in the common sulfides. Can. Mineral. 28, $1-16$.

CoоKe, D.R. \& McPhaIL, D.C. (2001): Epithermal Au-Ag-Te mineralization, Acupan, Baguio district, Philippines: numerical simulations of mineral deposition. Econ. Geol. 96, 109-131.

FinUCANE, K.J. \& JENSEN, H.E. (1953): Lode structures in the Kalgoorlie goldfield. In Geology of Australian Ore Deposits (first edition, A.B. Edwards, ed.). Fifth Emp. Mining Metall. Congress, Melbourne, Australia (94-111).

Gammons, C.H. \& Williams-Jones, A.E. (1995): Hydrothermal geochemistry of electrum: thermodynamic constraints. Econ. Geol. 90, 420-432.

Golding, L.Y. (1978): Mineralogy, Geochemistry and Origin of the Kalgoorlie Gold Deposits, Western Australia. Ph.D. thesis, Univ. of Melbourne, Melbourne, Australia.

Golding, S.D., Clark, M.E., Keele, R.A., Wilson, A.F. \& KEAYS, R.R. (1990): Geochemistry of Archean epigenetic gold deposits in the Eastern Goldfields Province, Western Australia. Geology Dep., University Extension, Univ. of Western Australia, Publ. 23, 141-176.

\& WILSON, A.F. (1983): Geochemical and stable isotope studies of the No. 4 lode, Kalgoorlie, Western Australia. Econ. Geol. 78, 438-450.

Groves, D.I. (1993): The crustal continuum model for lateArchaean lode-gold deposits of the Yilgarn Block, Western Australia. Mineral. Deposita 28, 366-374.

\& Phillips, G.N. (1987): The genesis and tectonic control on Archaean gold deposits of the Western Australian Shield - a metamorphic replacement model. Ore Geol. Rev. 2, 287-322.

Gustafson, J.K. \& Miller, F.S. (1937): Kalgoorlie geology re-interpreted. Austral. Inst. Mining Metall. Proc. 106, 93 125.

Hagemann, S.G. (1999): Hydrothermal Alteration, Pyrite Classification and Sulfur Isotope Data. Unpubl. Rep., Kalgoorlie Consolidated Gold Mines.

Bateman, R., Crowe, D. \& Vielreicher, R.M (1999): In situ sulfur isotope compositions of pyrites from the Fimiston- and Oroya-style gold lodes in the Golden Mile camp, Kalgoorlie: implications for sulfur source(s) and depositional processes. Geol. Soc. Am., Abstr. Programs 31(7), 32. 
HARRIS, D.C. (1989): The mineralogy and geochemistry of the Hemlo gold deposit, Ontario. Geol. Surv. Can., Econ. Geol. Rep. 38.

Ho, S.E. (1987): Fluid inclusions: their potential as an exploration tool for Archaean gold deposits. Geology Department (Key Centre), Univ. Ext., Univ. Western Australia, Publ. 11, 239-263.

BennetT, J.M., CAssidy, K.F., HRonsky, J.M.A., MiKUCKI, E.J. \& SANG, J.H. (1990): Fluid inclusion studies. In Gold Deposits of the Archean Yilgarn Block, Western Australia: Nature, Genesis and Exploration Guides (S.E. Ho, D.I. Groves \& J.M. Bennett, eds.). Geology Department (Key Centre), Univ. Ext., Univ. Western Australia, Publ. 20, 198-211.

Holroyd, A.G. (1897): The discovery and occurrence of telluride of gold upon the Kalgoorlie Goldfields, East Coolgardie District, Western Australia. Austral. Inst. Mining Engs., Trans. 4, 186-193.

Hopkins, G.M. (1965): Aspects of the Mineralogy and Structural Setting of Gold Ore, Perseverance Lode, Kalgoorlie. Ph.D. thesis, Imperial College, London, U.K.

KELLY, W.C. \& GodDARD, E.N. (1969): Telluride ores of Boulder County, Colorado. Geol. Soc. Am., Mem. 190.

Kent, A.J.R. \& McDougall, I. (1995): ${ }^{40} \mathrm{Ar}-{ }^{39} \mathrm{Ar}$ and U-Pb age constraints on the timing of gold mineralization in the Kalgoorlie gold field, Western Australia. Econ. Geol. 90, 845-859.

LARCOMBE, C.O.G. (1912): The geology of Kalgoorlie (Western Australia), with special reference to the ore-deposits. Austral. Inst. Mining Engs. Proc. 5, 1-312.

MACIVOR, R.W.E. (1899): On native tellurium from the Hannan's District, Western Australia. Chem. News 82, 2.

MARKHAM, N.L. (1960): Synthetic and natural phases in the system Au-Ag-Te. Econ. Geol. 55, 1148-1178, 1460-1477.

McQueEn, K.G., Bielin, S. \& LenNie, C.A. (1994): The nature of pyritic gold ores at Kalgoorlie, Western Australia: geological and metallurgical implications. Econ. Geol. Res. Unit, James Cook Univ. of North Queensland, Contrib. 51.

NeLson, D.R. (1997): Evolution of the Archaean granitegreenstone terranes of the Eastern Goldfields, Western Australia: SHRIMP U-Pb zircon constraints. Precamb. Res. 83, 57-81.

NiCKEL, E.H. (1977): Mineralogy of the "green leader" gold ore, Kalgoorlie, Western Australia. Austral. Inst. Mining Metall., Proc. 263, 9-13.

PhilLIPS, G.N. \& BRown, I.J. (1987): Host rock and fluid control on carbonate assemblages in the Golden Mile Dolerite, Kalgoorlie gold deposit, Australia. Can. Mineral. 25, 265273.
\& GiBB, H.F.C. (1993): A century of gold mining at Kalgoorlie. Econ. Geol. Res. Unit, James Cook Univ. of North Queensland, Contrib. 45.

, Amaro, D., Hallbaeur, D.K. \& Fotios, M.G. (1988): Morphology and trace-element compositions of pyrites from Kalgoorlie gold deposits: sensitive indicators of syndeformational fluid regimes and depositional processes. Geol. Dep., Univ. Ext., Univ. Western Australia, Publ. 12, 217-226.

Groves, D.I. \& KeRrich, R. (1996): Factors in the formation of the giant Kalgoorlie gold deposit. Ore Geol. Rev. 10, 295-317.

RADTKE, A.S. (1963): Data on cuprian coloradoite from Kalgoorlie, Western Australia. Econ. Geol. 58, 593-598.

REED, M.H. (1982): Calculations of multicomponent chemical equilibria and reaction processes in systems involving minerals, gases and an aqueous phase. Geochim. Cosmochim. Acta 46, 513-528.

\& SPYCHER, N.F. (1985): Boiling, cooling, and oxidation in epithermal systems: a numerical modeling approach. Rev. Econ. Geol. 2, 249-272.

RUCKLIDGE, J. \& STUMPFL, E.F. (1968): Changes in the composition of petzite $\left(\mathrm{Au}_{3} \mathrm{AgTe}_{2}\right)$ during analysis by electron microprobe. Neues Jahrb. Mineral., Monatsh., 61-68.

SCANTLEBURY, G.M. (1983): The Characterisation and Origin of the Gold Lodes in and Around the Brownhill Syncline, Golden Mile, Kalgoorlie, Western Australia. B.S. thesis (Honours), Univ. Western Australia, Perth, Western Australia.

SHACKLETON, J.M. (2002): Telluride Mineralogy of the Golden Mile, Kalgoorlie, Western Australia. M.S. thesis, Iowa State Univ., Ames, Iowa.

\& SPRY, P.G. (2003): Antimony-rich montbrayite $\left((\mathrm{Au}, \mathrm{Sb})_{2} \mathrm{Te}_{3}\right)$ from the Golden Mile, Western Australia, and its compositional implications. Neues Jahrb. Mineral. Monatsh., 113-125.

SimPSON, E.S. (1912): Detailed mineralogy of Kalgoorlie and Boulder, with special reference to the ore deposits. Bull. Geol. Surv. Western Australia 42, 77-151.

Spry, P.G., Foster, F., Truckle, J.S. \& Chadwick, T.J. (1997): The mineralogy of the Golden Sunlight gold-silver telluride deposit, Whitehall, Montana, U.S.A. Mineral. Petrol. 59, 143-164.

STILLwell, F.L. (1931): The occurrence of telluride minerals at Kalgoorlie. Austral. Inst. Mining Metall. Proc. 84, 115190.

(1953): Tellurides in Western Australia. In Geology of Australian Ore Deposits. Emp. Mining Metall. Congress (Montreal), 119-127. 
STOKES, P.A. (1989): Mineralogy and Geochemistry of the North Kalgurlie Mine Gold Ores, Kalgoorlie, Western Australia. M.S. thesis, Western Australian School of Mines, Curtin Univ. of Technology, Kalgoorlie, Australia.

Томісн, S.A. (1974): A new look at the Kalgoorlie Golden Mile geology. Austral. Inst. Mining Metall. Proc. 251, $27-$ 35

Travis, G.A. (1966): A Study of the Gold and Telluride Mineralisation at Kalgoorlie, Western Australia. M.S. thesis, Imperial College, London, U.K.

VAUGHAN, J.P. (1996): Preliminary report on the invisible gold content of Golden Mile pyrites. Unpubl. Rep., Kalgoorlie Consolidated Gold Mines.

Walshe, J.L., Halley, S.W., Hall, G.A. \& Kitto, P. (2003): Contrasting fluid systems, chemical gradients and controls on large-tonnage, high-grade Au deposits, eastern Goldfields Province, Yilgarn Craton, Western Australia. In Mineral Exploration and Sustainable Development (D.
Eliopoulos, ed.). A.A. Balkema, Lisse, The Netherlands (in press).

WEIR, R.H., JR. \& KERRICH, D.M. (1987): Mineralogic, fluid inclusion, and stable isotope studies of several gold mines in the Mother Lode, Tuolumne and Mariposa counties, California. Econ. Geol. 82, 328-344.

White, R.W., Powell, R. \& Phillips, G.N. (2003): A mineral equilibria study of the hydrothermal alteration in mafic greenschist facies rocks at Kalgoorlie, Western Australia. J. Metamorph. Geol. 21, 455-468.

Yeats, C.J. \& McNaughton, N.J. (1997): U-Pb geochronology on lode-gold deposits of the Yilgarn Craton. In Crustal Evolution, Metallogeny and Exploration of the Yilgarn Craton: an Update (K.F. Cassidy, A.J. Whitaker \& S.F. Liu, eds.). Aust. Geol. Surv. Org., Rec. 1997/41 (125-130).

Received April 10, 2003, revised manuscript accepted November 14, 2003. 